OUTBREEDING DEPRESSION IN HYBRIDS BETWEEN SPATIALLY

SEPARATED PINK SALMON (ONCORHYNCHUS GORBUSCHA) POPULATIONS:

MARINE SURVIVAL, HOMING ABILITY, AND VARIABILITY IN FAMILY SIZE

By

Sara Ellen Gil

RECOMMENDED:

APPROVED:
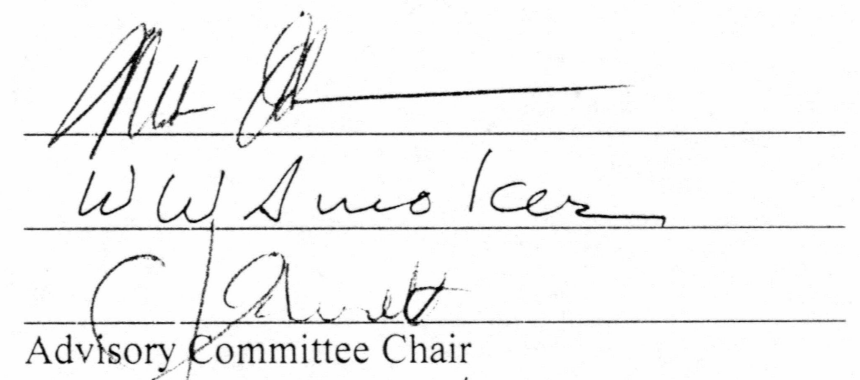

Advisory Committee Chair

wu l mokes

Dean, School of Fisheries and Ocean Sciences

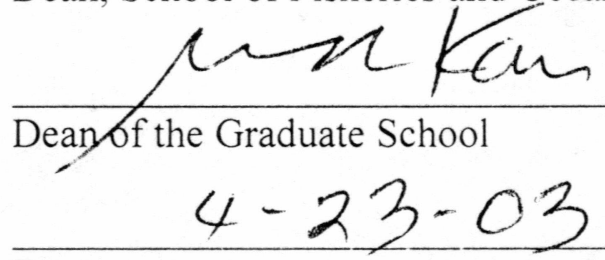

Date 


\title{
OUTBREEDING DEPRESSION IN HYBRIDS BETWEEN SPATIALLY \\ SEPARATED PINK SALMON (ONCORHYNCHUS GORBUSCHA) \\ POPULATIONS: MARINE SURVIVAL, HOMING ABILITY, AND VARIABILITY IN FAMILY SIZE
}

A

THESIS

\author{
Presented to the Faculty \\ of the University of Alaska Fairbanks \\ in Partial Fulfillment of the Requirements \\ for the Degree of \\ MASTER OF SCIENCE
}

By

Sara Ellen Gilk

ALASKA

QL

638

52

6547

2003

Fairbanks, Alaska

May 2003 


\begin{abstract}
Hybridization between distinct populations of salmon can cause fitness loss (outbreeding depression), and may result in reduced survival. The erosion of fitness-related traits such as homing ability and change in family size distribution may underlie reduced survival. Outbreeding depression was investigated in two independent experiments that made hybrids between geographically separated and genetically divergent pink salmon populations. Control crosses were made from male and female Auke Creek (Southeast Alaska) pink salmon and hybrid crosses were between Auke Creek females and Pillar Creek (Kodiak Island, about $1000 \mathrm{~km}$ away) males. Parentage assignment from microsatellite analysis improved estimates of survival and straying, and was used to examine variation in family size. The return rates of even-broodyear $F_{1}$ control and hybrid fish were similar, but the odd-broodyear $F_{1}$ control returns exceeded hybrid returns. The $\mathrm{F}_{2}$ control returns exceeded hybrid returns in both the even- and oddbroodyears. Hybridization did not impair homing ability; weekly surveys in nearby $(\sim 1 \mathrm{~km})$ Waydelich Creek revealed similar straying rates from Auke Creek by both hybrid and control fish in all years. Family data were available only for even-broodyear returns; hybridization did not increase the index of variability (ratio of variance to mean) in family size in these years. Outbreeding depression in hybrids of geographically separated populations demonstrates the potential for introgression of nonnative fish to erode natural production.
\end{abstract}




\section{Table of Contents}

Abstract......................................................................

List of Figures......................................................... vi

List of Tables............................................................. viii

List of Appendices.................................................. $\quad x$

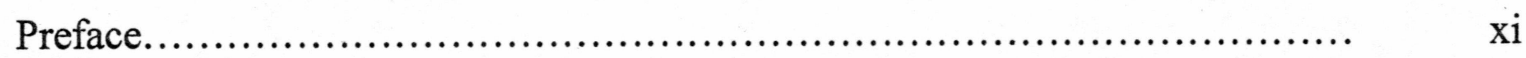

General Introduction.................................................... 1

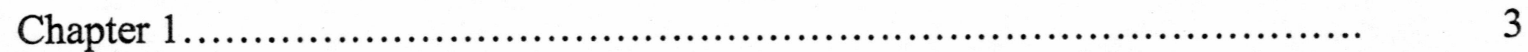

Synopsis.................................................... 4

Introduction.................................................... 5

Materials and Methods............................................ 9

Crosses and incubation procedures......................... 9

Survival and straying in even- and odd-broodyears............. 11

Microsatellite and parentage analysis........................ 12

Variance in family size of even-broodyears................... 14

Results....................................................... 15

Microsatellite variation in Auke and Pillar creek, and parentage

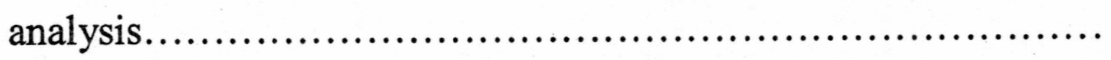

Survival and straying in even- and odd-broodyears............. 17

Inbreeding in even- and odd-broodyears..................... 18

Variance in family size of even-broodyears.................... 18 
Discussion.......................................................... 19

Microsatellite variation in Auke and Pillar creek, and parentage analysis..................................................... 19

Survival and straying in even- and odd-broodyears............... 19

Inbreeding in even- and odd-broodyears...................... 22

Variance in family size of even-broodyears..................... 23

Conclusion........................................................ 24

Figures....................................................... 25

Tables............................................................... 26

References Cited................................................... 28

Appendices............................................................ 36

General Conclusion........................................................ 56 


\section{List of Figures}

Figure 1 Individual family sizes for even-broodyear $\mathrm{F}_{1}$ and $\mathrm{F}_{2}$ pink salmon returns to Auke Creek...................................................... 25

Figure A.1. Map of study area........................................... 36

Figure B.1. Replicated incomplete-factorial mating design used for experiments $\quad 37$

Figure D.1. Homogeneity of allele frequencies at the Ogola and Oki10 microsatellite loci between Auke Creek and Pillar Creek pink salmon used for

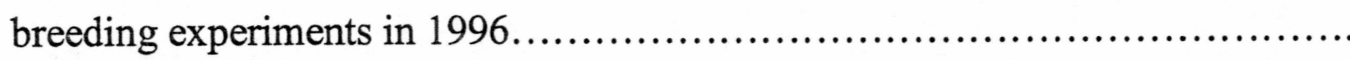

Figure D.2. Homogeneity of allele frequencies at the Oki11 and Ots 103 microsatellite loci between Auke Creek and Pillar Creek pink salmon used for breeding experiments in 1996.

Figure D.3. Homogeneity of allele frequencies at the Ots 1 and Ssa 197

microsatellite loci between Auke Creek and Pillar Creek pink salmon used for breeding experiments in 1996.

Figure D.4. Homogeneity of allele frequencies at the Ogola and Oki10 microsatellite loci between Auke Creek and Pillar Creek pink salmon used for

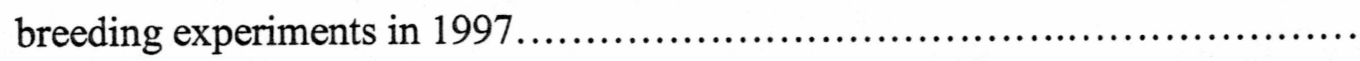

Figure D.5. Homogeneity of allele frequencies at the Oki11 and Ots 103 microsatellite loci between Auke Creek and Pillar Creek pink salmon used for

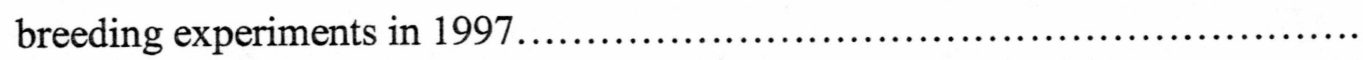


Figure D.6. Homogeneity of allele frequencies at the Ots1 and Ssa197 microsatellite loci between Auke Creek and Pillar Creek pink salmon used for

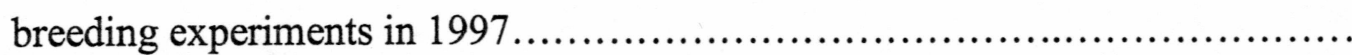




\section{List of Tables}

Table 1. Number of released fry and returning adults for $F_{1}$ and $F_{2}$ pink salmon controls and hybrids.

Table 2. Number of returning adult pink salmon recovered at Waydelich Creek

Table C.1. Microsatellite loci used for pink salmon parentage analysis.

Table E.1. Observed allele frequencies for the Ogola microsatellite locus in Auke and Pillar Creek pink salmon used for breeding experiments in 1996 and 1997

Table E.2. Observed allele frequencies for the Oki10 microsatellite locus in Auke and Pillar Creek pink salmon used for breeding experiments in 1996 and 1997

Table E.3. Observed allele frequencies for the Oki11 microsatellite locus in Auke and Pillar Creek pink salmon used for breeding experiments in 1996 and 1997

Table E.4. Observed allele frequencies for the Ots 103 microsatellite locus in Auke and Pillar Creek pink salmon used for breeding experiments in 1996 and 1997

Table E.5. Observed allele frequencies for the Ots 1 microsatellite locus in Auke and Pillar Creek pink salmon used for breeding experiments in 1996 and 1997 
Table E.6. Observed allele frequencies for the Ssa 197 microsatellite locus in Auke and Pillar Creek pink salmon used for breeding experiments in 1996 and 1997 


\section{List of Appendices}

Appendix A: Map of study area....................................... 36

Appendix B: Mating design........................................ 37

Appendix C: Microsatellite loci..................................... 38

Appendix D: Homogeneity of allele frequencies......................... 39

Appendix E: Allele frequencies..................................... 45 


\section{Preface}

The work in this thesis has been submitted and tentatively accepted for publication in a dedicated issue of the journal Environmental Biology of Fishes (published by Kluwer Academic Publishers) as part of the proceedings from the $20^{\text {th }}$ Lowell Wakefield Fisheries Symposium on Genetics of Subpolar Fish and Invertebrates. The authorship on the paper is S.E. Gilk, I.A. Wang, C.H. Hoover, W.W. Smoker, S.G. Taylor, A.K. Gray, and A.J. Gharrett. I conducted all the microsatellite and data analysis, nursed one generation of pink salmon, directed recovery efforts for one generation of fish, and wrote the manuscript. A.J. Gharrett and W.W. Smoker designed and set up the experiments. I.A. Wang maintained the first three generations of fish, oversaw clipping in these years, and directed recoveries of returning fish for the first returns. C.H. Hoover facilitated collections of returning fish in the final returns, and will evaluate family size in the much larger odd-broodyear returns in her thesis. S.G. Taylor is manager of the Auke Creek weir and hatchery and is responsible for capturing the returning fish at the weir. A.K. Gray provided laboratory guidance.

This thesis would not have been possible without the help of M. Adkison, S. Hall, Z. Li, J. Lum, A. Matala, E. Peterson, and the many others who assisted in seining efforts, tissue collections, and breeding experiments. Many thanks to my committee members for their guidance and support. Thanks also to my family and friends for their continued patience and encouragement.

The U.S. National Marine Fisheries Service Auke Bay Fisheries Laboratory, the Alaska Department of Fish and Game, and the University of Alaska Fairbanks cooperated 
in operation of the Auke Creek weir. This publication is the result of research sponsored by Alaska Sea Grant with funds from the National Oceanic and Atmospheric Administration Office of Sea Grant, Department of Commerce, under grant no. NA 16RG2321 (project nos. R/31-06 and R/31-02), and from the University of Alaska with funds appropriated by the state. 


\section{General Introduction}

Experiments demonstrating the genetic impact of cultured fish on wild stocks are rare (Campton 1995). One of the possible effects is reduced survival in hybrids between cultured and wild stocks, an effect called outbreeding depression. Relatively few studies of outbreeding depression have been made (i.e. Philipp \& Claussen 1995, Gharrett \& Smoker 1991, Gharrett et al. 1999), and little has been done to evaluate the potential of outbreeding depression in salmonids even though management practices may put endemic populations at risk by introducing alien stocks.

This thesis is part of an ongoing outbreeding depression study of pink salmon returning to Auke Creek, near Juneau, Alaska that will eventually contribute to the theses of several graduate students. A hatchery and permanent weir located just above tidewater aids in the collection of donors and experimental fish, as well as in monitoring upstream and downstream migrations. Previous studies conducted at Auke Creek demonstrated a genetic component in emigration timing of pink salmon (Lane et al. 1990, McGregor et al. 1998, Smoker et al. 1998), and that outbreeding depression occurs in hybrids between odd- and even-broodyear pink salmon. Gharrett \& Smoker (1991) observed that $F_{1}$ hybrid and control survival rates were similar but that there appeared to be a decrease in survival and increase in bilateral asymmetry in $\mathrm{F}_{2}$ hybrids (although no controls were available). When these experiments were repeated to include controls, Gharrett et al. (1999) observed significantly higher returns in $F_{2}$ controls than in $F_{2}$ hybrids, but no differences in bilateral asymmetry. Since these hybrids did not represent crosses that might occur naturally or as a result of management practices, experiments were initiated 
in 1996 to examine the outbreeding depressive effects of hybridization of spatially separated pink salmon from Auke Creek and Pillar Creek, Kodiak Island (great circle distance $1048 \mathrm{~km}$ ). If outbreeding depression is detectable in populations as genetically disparate as even- and odd-brood year pink salmon, subsequent experiments involving less distant populations within the same broodyear will provide insight into the extent of genetic divergence necessary to produce outbreeding depression.

Observations of survival are the most direct way to quantify outbreeding depression; however, fitness-related traits such as homing ability and changes in the distribution of family size may underlie a decrease in survival. Therefore, the experiment included the identification of families from which inbreeding coefficients can be determined and from which the distributions of family size could be described. In this thesis, survivals of both the first and second generation returns of even- and oddbroodyear experiments are reported. In addition, analysis of straying and inbreeding depression are presented. The analysis of family size is restricted to the even-broodyear; C. Hoover is examining the larger returns of the odd-broodyear. 
Outbreeding depression in hybrids between spatially separated pink salmon (Oncorhynchus gorbuscha) populations: Marine survival, homing ability, and variability in family size ${ }^{1}$

Sara E. Gilk ${ }^{\mathrm{a}}$, Ivan A. Wang ${ }^{\mathrm{a}}$, Carrie H. Hoover ${ }^{\mathrm{a}}$, William W. Smoker ${ }^{\mathrm{a}}$, S.G. Taylor ${ }^{\mathrm{b}}$, Andy K. Gray ${ }^{\mathrm{a}, \mathrm{b}}$, \& A.J. Gharrett ${ }^{\mathrm{a}, \mathrm{c}}$

${ }^{a}$ Fisheries Division, School of Fisheries and Ocean Sciences, University of Alaska Fairbanks, 11120 Glacier Highway, Juneau, AK 99801, U.S.A.

${ }^{b}$ Auke Bay Laboratory, Alaska Fisheries Science Center, National Marine Fisheries Service, NOAA, 11305 Glacier Highway, Juneau, AK 99801, U.S.A.

${ }^{c}$ Corresponding author (e-mail: ffajg@uaf.edu)

Key words: conservation biology, local adaptation, microsatellites, salmonid

${ }^{1}$ Submitted for publication to Environmental Biology of Fishes. 


\section{Synopsis}

Hybridization between distinct populations and introgression of nonnative genes can erode fitness of native populations through outbreeding depression, either by producing a phenotype intermediate to that of both contributing genomes (and maladapted in either population's environment) or by disrupting distinct coadapted complexes of epistatic genes. In salmon, fitness-related traits such as homing ability or family-size distribution may be eroded. We investigated geographically separated pink salmon populations in repeated trials in independent broodyears (odd and even). Hybrids were made between female Auke Creek (Southeast Alaska) pink salmon and Pillar Creek (Kodiak Island, $\sim 1000 \mathrm{~km}$ away) males; hybrids and their offspring were compared to offspring of control crosses of the same females with Auke Creek males. Parentage assignment from microsatellite analysis was used to improve estimates of survival and straying and to examine variation of family size. Hybridization reduced return rates of adults (a proxy for survival at sea) in the $F_{1}$ generation in the odd-year broodline $(p<0.0001)$ but not in the even-year broodline $(p=0.678)$. Hybridization reduced survival in both the odd- and even-broodyear $\mathrm{F}_{2}(\mathrm{p}<0.005$ and $\mathrm{p}<0.0001)$. Hybridization did not appear to impair homing ability; weekly surveys revealed similar straying rates $(\sim 2 \%)$ by both hybrid and control fish into nearby $(\sim 1 \mathrm{~km})$ Waydelich Creek in both generations in both trials. Hybridization did not increase the index of variability $\left(\sigma^{2} / \mu\right)$ in family size. Decreased survival in the hybrid $F_{2}$ generation supports an epistatic model of outbreeding depression; nonepistatic effects may have contributed to reduced survival in the oddbroodyear $F_{1}$ hybrid fish. Outbreeding depression in hybrids of geographically separated 
populations demonstrates that introgression of nonnative fish can erode fitness, and should be recognized as a potential detriment of both aquaculture and management practices.

\section{Introduction}

Pacific salmon (Oncorhynchus spp.) have been transplanted between zoogeographic regions and between watersheds within regions and have been artificially produced and released in large numbers for over a century, generally for harvest enhancement and species restoration or mitigation for lost habitat (reviewed by Lichatowich 1999). Pacific salmon generally home to natal sites for spawning, thereby promoting reproductive isolation and exposing populations to diversifying selective pressures (Carvalho 1993). Releases of cultured or transplanted fish into environments inhabited by indigenous salmonid populations remove natural barriers to gene flow between populations. Recurrent introgression from transplanted fish or a hatchery stock derived by transplantation may alter the structure of locally-evolved genomes, thereby reducing the fitness of the local populations (Hindar et al. 1991, Campton 1995). Although introductions of hatchery-raised fish may aid in restoration of populations at risk of extinction or may increase the productivity of populations in degraded habitat, hybridization between salmon populations adapted to different local environments can also reduce the average fitness of wild salmon populations, known as outbreeding depression (Shields 1982, Hard 1995). 
Outbreeding depression can result from an additive combination of average genetic values in the parental populations, disruption of an epistatic interaction among alleles at different loci, or both. A fitness loss expected from non-epistatic effects would occur in the first $\left(\mathrm{F}_{1}\right)$ and subsequent generations. Examples include intermediate resistance to Ceratomyxa shasta in hybrids between resistant and nonresistant coho salmon (O. kisutch) stocks (Hemmingson et al. 1986) and reduced tolerance to DDT in $\mathrm{F}_{1}$ mosquitoes (King 1955).

Reproductively isolated populations may also evolve different genomes comprising coadapted, epistatic genes (Wallace 1981, Lynch 1991). Hybridization would disrupt the coadapted genomes (Dobzhansky 1950), but disruption may not appear in $F_{1}$ hybrids because each offspring possesses a complete coadapted genome from each parent. In fact, hybrid individuals may demonstrate heterosis (hybrid vigor; Emlen 1991), but reduction in fitness would be expected in the second $\left(F_{2}\right)$ and later generations (Dobzhansky 1950). Outbreeding depression from a disrupted coadapted genome has been suggested in several species (e.g., Dobzhansky 1948, 1950, Brncic 1954, Gordon \& Gordon 1957, Leberg 1993, Philipp \& Claussen 1995), including salmonids (Gharrett \& Smoker 1991, Danzmann et al. 1999, Gharrett et al. 1999).

Outbreeding depression may be directly observed as reduced survival. It may also be observed in the degradation of individual traits related to fitness such as impaired homing ability or of population traits such as a change in the distribution of family size distribution. Homing ability has been suggested as an important adaptive trait that responds to local selective pressures such as stream stability (Quinn 1993). Obvious 
changes in homing ability may reflect changes in population fitness. In a previous transplantation and hybridization study on pink salmon, both hybrids and transplants had similar survivals; however, many fewer transplants than hybrid native/transplanted salmon negotiated their way to the release site, suggesting that terminal homing may have a genetic basis (Bams 1976). However, transplantation/hybridization studies have not followed hybrids into the $F_{2}$ generation where outbreeding depression would be expected (reviewed by Quinn 1993).

Changes in family size distribution may also reflect fitness loss. Genetic differences between families may result in different responses (survival) to variable marine conditions. Consequently, some families of a particular generation are better adapted to particular environmental conditions, but the most favored genotypes may change from generation to generation (Geiger et al. 1997) as conditions fluctuate. Hybridization might reduce the number of contributing families such that a small number of parents contribute disproportionately to subsequent generations. Coupled with genetic drift, this may increase inbreeding and decrease the effective population size. A smaller effective population size would tend to reduce genetic variability and most likely the average fitness of a population (Falconer \& Mackay 1996) and could exacerbate outbreeding depression due to stochastic losses of essential alleles (Nevo et al. 1986, Emlen 1991). Observations of nonrandom variation of marine survival between families of Pacific salmon populations (Simon et al. 1986, Geiger et al. 1997, Hard et al. 2000) underscore the importance to population fitness of maintaining genetic variation in a population. 
Molecular markers make it possible to reconstruct pedigrees. The parental sources of returning fish can be confirmed, and family size distributions can be determined from these data. Polymorphic microsatellite loci provide information on parent-offspring relationships and have been used to study parentage in many species, including fishes (e.g. Estoup et al. 1998, Waldbieser \& Wolters 1999).

Previous work at Auke Creek studied the survivals of hybrids between odd- and even-broodyear pink salmon. Gharrett \& Smoker (1991) observed that $F_{1}$ hybrid and control survival rates were similar, and observations of $\mathrm{F}_{2}$ hybrids suggested a decrease in survival, although controls were not possible. When these experiments were repeated to include controls, returns of $\mathrm{F}_{2}$ controls exceeded returns of $\mathrm{F}_{2}$ hybrids (Gharrett et al. 1999). Hybrids between broodyears do not represent crosses that are likely to occur naturally or as the result of management practices; therefore, this study was begun in 1996 to examine the outbreeding depressive effects of hybridization of spatially separated pink salmon from the same broodyear.

Our objective was to examine the effects of hybridization between pink salmon from widely separated populations. To accomplish this objective, hybrids were produced between pink salmon from Auke Creek near Juneau, Alaska and Pillar Creek on Kodiak Island and controls that had only Auke Creek parents; marine survivals were observed in both $F_{1}$ and $F_{2}$ generations. The effects of hybridization on two fitness related traits, homing ability and the distribution of family size, are examined here. Parentage determined from microsatellite inheritance was used to improve estimates of survival and straying and to examine family size distributions. Evidence of outbreeding depressive 
effects on survival suggests additive effects on one of the $F_{1}$ hybrids and epistatic effects in both $F_{2}$ hybrids. There was no evidence of an effect on either homing ability or family size distribution, which suggests that these mechanisms may not be important contributors to decreased survival.

\section{Materials and methods}

\section{Crosses and incubation procedures}

The experiments evaluated hybrids between pink salmon from two Alaskan populations: Auke Creek near Juneau, Alaska (58 $\left.23^{\prime} \mathrm{N}, 134^{\circ} 37^{\prime} \mathrm{W}\right)$ and Pillar Creek on Kodiak Island $\left(57^{\circ} 47^{\prime} \mathrm{N}, 152^{\circ} 28^{\prime} \mathrm{W}\right)$. Auke Creek, a lake-fed stream of moderate grade, is about $350 \mathrm{~m}$ long and has spawning populations that vary between 2,000 and $20,000^{2}$. Pillar Creek is a reservoir-fed stream of shallow gradient, runs about $1800 \mathrm{~m}$, and has spawning populations that vary between 1,000 and $40,000^{3}$. The distance between these streams (great circle distance $1048 \mathrm{~km}$; the continental shelf distance is considerably greater) prevents direct gene flow between the populations, even though they are at the same latitude (Appendix A).

The first generation hybrids were made at Auke Creek in 1996 and 1997 in an experiment that modeled Auke Creek as the recipient of a transplantation and Pillar Creek as the donor population. The mating scheme, a blocked incomplete-factorial

\footnotetext{
2 Taylor, S.G. \& J.L. Lum. 2002. Annual Report Auke Creek Weir 2001: Operations, Fish Counts, and Historical Summaries. Unpublished Report 37 p. National Marine Fisheries Service. Auke Bay Laboratory, 11305 Glacier Highway, Juneau, Alaska 99801-8626.

3 Alaska Department of Fish and Game, Kodiak. 2000. Stream survey data of Pillar Creek, Kodiak, AK from 1968 to 2000 . Unpublished data.
} 
design (Appendix B), was intended for quantitative genetic analyses not reported here. Eggs of each of 40 Auke Creek females were divided between hybrid and control lines. Two Auke Creek males and two Pillar Creek males were crossed with each of two females (hereafter referred to as a "block") to make control and hybrid crosses. Twenty different blocks were produced by mating 40 Auke Creek males, 40 Auke Creek females, and 40 Pillar Creek males.

Each family was subdivided into two portions that were randomly assigned to incubation cells in vertical FAL ${ }^{\mathrm{TM}}$ incubators partitioned with dividers (MariSource, Milton, WA). Hybrid families were incubated in different cabinets than control families; however, high flow from a common water source maintained very similar environmental conditions in the two incubators; temperature records of each incubator document virtually identical temperature regimes. Embryos were reared until about $5 \%$ of their yolk remained, when they were differentially marked by mirror image pelvic fin excisions and an experiment-identifying adipose fin excision. The polarity of the marks was alternated between hybrid and control groups over the years of the experiment. About 20,000 hybrid and 20,000 control fish were released each spring, and equal numbers of each family were released when possible. The fry were released at the peak of emigration of the wild fish in Auke Creek.

Returning $F_{1}$ individuals were bred in 1998 and 1999. To produce each of 20 blocks of $F_{2}$ control and 20 blocks of hybrid progeny, two control males were crossed with each of two control females, and two hybrid males were crossed with each of two hybrid females. The control blocks included $40 \mathrm{~F}_{1}$ Auke Creek males and $40 \mathrm{~F}_{1}$ Auke 
Creek females; the hybrid blocks had $40 \mathrm{~F}_{1}$ hybrid males and $40 \mathrm{~F}_{1}$ hybrid females. About $20,000 \mathrm{~F}_{2}$ hybrid and $20,000 \mathrm{~F}_{2}$ control fish were differentially clipped and released at the peak of the emigration of the wild fish in Auke Creek in mid-April of 1999 and 2000.

Survival and straying in even- and odd-broodyears

Returning $F_{1}$ and $F_{2}$ adults were recovered in August and September 1998-2001 at a permanent weir located just above the high tideline at Auke Creek. During the return, intertidal Auke Creek and all of nearby Waydelich Creek were surveyed weekly with beach seines and dipnets during the spawning period in order to collect straying experimental fish. Survival was defined as return to the weir or recovery in a survey. Fish recovered at the weir were held in pens until they could be used for crosses or processed for data. The carcass of each returning fish was tagged, its fin mark (designating hybrid or control) and sex noted, and heart or muscle tissue samples were taken for genetic analysis. The equality of rates of survival and straying between groups was tested using log-likelihood ratios, (G-tests; Sokal \& Rohlf 1995). Parentage information from microsatellite analysis was used to improve estimates of survival and straying made from observation of marks by confirming the parental origin (control or hybrid) of returning fish, including those that had indistinct fin excisions. 


\section{Microsatellite and parentage analysis}

Tissues taken for DNA analysis were placed in preservative (Seutin et al. 1991) and stored at $-20^{\circ} \mathrm{C}$ prior to DNA extraction. Total DNA was isolated with Puregene DNA ${ }^{\mathrm{TM}}$ isolation kits (Gentra Systems, Inc., Minneapolis, MN). Polymerase chain reaction (PCR) amplification was done in 96-well microtitre plates in a Stratagene 96 Robocycler. Reactions were performed in $10 \mu \mathrm{L}$ volumes $[10 \mathrm{mM}$ Tris- $\mathrm{HCl}$ at $\mathrm{pH} 8.3,50 \mathrm{mM} \mathrm{KCl}$, $25 \mathrm{mM} \mathrm{MgCl}_{2}, 2.5 \mathrm{mM}$ each deoxyribonucleotide triphosphate (dNTP), 0.5 units Taq polymerase, $0.1-0.5 \mu \mathrm{M}$ each primer, and 50-100 ng DNA template] overlaid with mineral oil. In addition to unlabeled forward and reverse primers for each locus, each mixture included a forward primer labeled with an infrared-sensitive dye, IRDye ${ }^{\mathrm{TM}}$ (LICOR, Inc., Lincoln, NE). After evaluating several microsatellite loci, six loci were chosen (Appendix C): Ssa197 (O’Reilly et al. 1996), Ots1 (Banks et al. 1999), Ots103 (Small et al. 1998), Ogola (Olsen et al. 1998), and Oki10 and Oki11 (Smith et al. 1998). In general, PCR conditions were as follows: 1 cycle at $95^{\circ} \mathrm{C}$ for 3 minutes; 30 cycles at $95^{\circ} \mathrm{C}$ for 1 minute, $x^{\circ} \mathrm{C}$ for 1 minute, and $72^{\circ} \mathrm{C}$ for 1 minute; and finally 1 cycle at $72^{\circ} \mathrm{C}$ for 5 minutes; where $x$ is the annealing temperature $\left(52^{\circ} \mathrm{C}\right.$ for $S s a 197,49^{\circ} \mathrm{C}$ for $O t s 1$, $47^{\circ} \mathrm{C}$ for $O t s 103,59^{\circ} \mathrm{C}$ for $O g o 1 \mathrm{a}, 55^{\circ} \mathrm{C}$ for $O k i 10$, and $53^{\circ} \mathrm{C}$ for $O k i 11$ ). After amplification, DNA products were denatured by adding an equal volume of stop buffer ( $95 \%$ formamide, $0.1 \%$ Bromophenol Blue) and heating for 3 minutes at $95^{\circ} \mathrm{C}$. Finally, $1-1.5 \mu \mathrm{L}$ of PCR product was loaded onto polyacrylamide denaturing gels composed of 6\% PAGE-PLUS ${ }^{\mathrm{TM}} 40 \%$ Concentrate (AMRESCO, Inc., Solon, OH), $7 \mathrm{M}$ urea, and $5 \mathrm{X}$ TBE (TBE is $90 \mathrm{mM}$ tris-boric acid and $2 \mathrm{mM}$ EDTA, $\mathrm{pH} 7.5$ ) in a reaction catalyzed by 
ammonium persulfate and TEMED (N,N,N',N' tetramethylethylenediamine).

Electrophoresis and detection were performed on a LI-COR automated sequencer (LongReadIR $4200^{\mathrm{TM}}$, LI-COR, Inc., Lincoln, NE) in $1 \mathrm{X}$ TBE running buffer, with running parameters $31.5 \mathrm{~W}, 1500 \mathrm{~V}, 35 \mathrm{~mA}$, and $50^{\circ} \mathrm{C}$ plate temperature. GeneImagIR RFLPscan software (Version 3.52, Scanalytics, LI-COR, Inc., Lincoln, NE) was used to estimate the sizes of microsatellite alleles. Allele sizes were determined by comparing allele band patterns with IRD $700^{\mathrm{TM}}$ or IRD $800^{\mathrm{TM}}$ standard ladders (LI-COR, Inc., Lincoln, NE) and standardized using reference alleles.

Allele frequencies were estimated for the Auke and Pillar Creek populations for both even- and odd-broodline crosses. GenePop version 3.2a (Raymond \& Rousset 1995) was used to test conformance to Hardy-Weinberg expectation using the following parameters: 10,000 dememorization steps, 1000 batches, and 1000 iterations per batch. Excess homozygosity can be an indication of null alleles, which complicate parentage analysis.

To demonstrate genetic differences between the Auke and Pillar Creek populations, allele frequencies were estimated for both the even- and odd-broodline parents. Homogeneity of allele frequencies between populations at all six loci was tested using a $G$-test for which the probability levels were estimated by 20,000 iterations in a Monte-Carlo simulation (e.g. Roff \& Bentzen 1989). Probabilities were combined to examine overall heterogeneity for each broodyear using Fisher's method (Winer 1971).

Parentage of each returning fish was deduced using PROBMAX with default tolerance levels and allowing mis-scored loci (Version 1.2, Danzmann 1997). Parentage 
information was used to confirm parental origins of well-marked fish, to determine parental origins (control, hybrid, or not experimental) of fish returning with indistinct marks, and to estimate family size of the even-broodyear returns. The parentage information also made it possible to estimate inbreeding coefficients (F; defined as the probability that alleles at a locus in an individual are identical by descent) in each segment of the experiment to determine if inbreeding had been imposed as a result of the limited sample of parents in the $F_{2}$ crosses (Falconer \& Mackay 1996). The inbreeding coefficient was calculated assuming that $1 / 2 N$ is the probability that uniting gametes have identical genes.

\section{Variance in family size of even-broodyears}

The underlying model for the estimation of effective population size is that the family size is approximately distributed as a Poisson. An increase in variance in a population (for a given mean) reduces the effective population size (Crow \& Kimura 1970), a possible consequence of outbreeding depression that could occur if only a few families produced most of the offspring.

The observed family sizes in the even-broodyear $F_{1}$ and $F_{2}$ hybrid and control returns were compared to expected Poisson distributions of average family size with a goodness of fit $G$-test (Sokal \& Rohlf 1995). Then, to avoid effects of correlations between families, the data blocks were randomly reduced to single full-sib families and bootstrapped. The bootstrap analysis randomly reduced the data so that each female in the analysis was assigned to a single control male and a single hybrid male. 
Consequently, the program randomly chose one control male and one hybrid male for the first female in each block and assigned the other males to the second female in the block. These bootstrap values were used to compare the means and variances of the distribution of family sizes of $F_{1}$ and $F_{2}$ returns, and to estimate the index of variability in family size. The index of variability contrasts the variance and mean in family size $\left(\sigma^{2} / \mu\right)$, and tends to 1 under random survival (Crow \& Morton 1955), which is the Poisson expectation. A larger index of variability in hybrids than controls may indicate that increased variability in family size contributed to a reduction in survival.

\section{Results}

Microsatellite variation in Auke and Pillar creek, and parentage analysis Homogeneity tests showed significant divergence between 40 Pillar Creek pink salmon and 80 Auke Creek pink salmon used for parentage in each $F_{1}$ experiment (Appendix D). Two loci in the even-broodyear (1996) samples showed significant heterogeneity between the populations (Ogo1a, p < 0.001; Oki11, p < 0.001) and four loci in the oddbroodyear (1997) samples showed significant heterogeneity (Oki10, p < 0.0001; Ogo1a, $\mathrm{p}<0.01 ;$ Ots 103, $\mathrm{p}<0.01 ;$ Oki11, $\mathrm{p}<0.01$ ). The probabilities combined across loci demonstrated overall heterogeneity between the Auke Creek and Pillar Creek pink salmon populations used in breeding experiments in both the even- and odd-broodyears (both $\mathrm{p}<0.0001$ ). Homogeneity tests based on genotype frequencies had similar results.

Not all loci conformed to expected Hardy-Weinberg frequencies. Tests of HardyWeinberg suggested the presence of null alleles at two loci: Ssa197 and Ots103. 
Pedigree information from progeny was used to reconstruct Ssa197 genotypes and identify null alleles. There was insufficient pedigree information available to reconstruct all of the Ots 103 genotypes. However, the high variability at most of the loci made all of the loci useful in contributing to parentage analyses. (See Appendix E for allele frequencies.)

Microsatellite markers were used to determine parentage of all even-broodyear fish, the odd-broodyear fish used for breeding experiments, and the returning oddbroodyear fish that had indistinct marks. Of 355 fish carrying indistinct fin marks, microsatellites revealed the parentage of 327 fish. The remaining 28 fish to which parents could not be assigned were included in hybrid counts to provide conservative hybrid survival estimates. Of the 1266 individual progeny with distinct fin excisions that were genotyped, 59 did not correspond to combinations of parents that were recorded when the matings were conducted; these fish were excluded from subsequent analyses. The seven fish with undetermined parentage that contributed to the odd-broodyear $F_{1}$ broodstock probably resulted from misreading fin marks when matings were conducted. These seven fish and their progeny were not included in estimates of the inbreeding coefficient of odd-broodyear fish. In both the even- and odd-broodyear $F_{1}$ breeding experiments, one individual was bred as a hybrid even though subsequent microsatellite genotyping indicated it was a control fish. Blocks including these eight fish were removed from analyses. 
Survival and straying in even- and odd-broodyears

The $\mathrm{F}_{1}$ generation fish from even-broodyear experiments returned to Auke Creek in 1998 (Table 1); returns (survival rates of fry to adulthood) of $F_{1}$ control $(1.43 \%)$ and hybrid (1.41\%) fish were nearly identical. $F_{1}$ odd-broodyear fish returned to Auke Creek in 1999; the $F_{1}$ control return $(5.14 \%)$ exceeded $(p<0.0001)$ that of $F_{1}$ hybrid fish $(3.67 \%)$. In 2000 , returns of even-broodyear $F_{2}$ fish $(0.88 \%)$ were higher $(p<0.0001)$ than $F_{2}$ hybrid returns $(0.54 \%)$. Similarly, odd-broodyear $\mathrm{F}_{2}$ control returns $(1.27 \%)$ exceeded $F_{2}$ hybrid returns $(0.96 \%)$ in $2001(\mathrm{p}<0.005)$.

Survival rates ${ }^{4}$ of cultured fish in these experiments were lower than those of wild fish returning to Auke Creek in all years. In the even-broodyears, returns of wild fish (7.29\% and 4.07\%, respectively) exceeded those of cultured fish. In odd-broodyears, survival of wild fish ( $46.3 \%$ and $5.95 \%$, respectively) was also higher than that of cultured fish.

Weekly recovery efforts in nearby (about $1 \mathrm{~km}$ ) Waydelich Creek revealed similar straying rates (about $2 \%$ or less) of both hybrid and control fish in all years (Table 2). Although the straying rates of hybrid fish were higher than those of the control fish, the straying rates were too low to detect statistical differences. The levels of straying do not appear to compensate for the much larger differences in return rate.

\footnotetext{
${ }^{4}$ Survival rates were estimated from counts of fry passing the weir in spring and adults passing the weir in summer of the following year. Data can be found in: Taylor, S.G. \& J.L. Lum. 2002. Annual Report Auke Creek Weir 2001: Operations, Fish Counts, and Historical Summaries. Unpublished Report 37 p. National Marine Fisheries Service. Auke Bay Laboratory, 11305 Glacier Highway, Juneau, Alaska 99801-8626.
} 


\section{Inbreeding in even- and odd-broodyears}

Inbreeding in the hybrid $F_{2}$ generations did not result from the choice of parents in either the even- or odd-broodyear $F_{1}$ generations. The even-broodline $F_{2}$ inbreeding coefficient for controls $(F=0.034)$ exceeded that of $F_{2}$ hybrids $(F=0.003)$. Similarly, in the oddbroodline, the inbreeding coefficient for $F_{2}$ controls $(F=0.013)$ was higher than that of $F_{2}$ hybrids $(\mathrm{F}=0.006)$. Both hybrid broodlines had low inbreeding coefficients that were similar to those expected theoretically $(\mathrm{F}=0.003)$.

\section{Variance in family size of even-broodyears}

Parentage data of the $F_{2}$ generation were available only for the even-broodyear returns.

Distributions of the $F_{1}$ control and hybrid offspring were not Poisson (Figure $1 ; p<0.001$ and $\mathrm{p}<0.01$ respectively, $G$-test). Removing an outlier in the $\mathrm{F}_{1}$ control group did not alter the results. The distribution of $F_{2}$ control family size was not Poisson $(p<0.001)$. However, the distribution observed for the $\mathrm{F}_{2}$ hybrid family size was weakly consistent with a Poisson distribution $(\mathrm{p}=0.051)$.

The index of variability did not increase in either the controls (2.91 and 1.78 for the $F_{1}$ and $F_{2}$ generations, respectively) or the hybrids (1.76 and 1.30 for the $F_{1}$ and $F_{2}$ generations, respectively). In addition, the index of variability in the $F_{2}$ hybrids did not exceed that of controls in either the $F_{1}$ or $F_{2}$ generation. Removing an outlier in the $F_{1}$ control group did not change these results. 


\section{Discussion}

Microsatellite variability in Auke and Pillar creek, and parentage analysis

Outbreeding depression is most likely to occur in hybrids of geographically separated populations if there is no direct gene flow and they have evolved separately for a considerable time. By choosing populations from approximately the same latitude, we attempted to match environments, though the match was not perfect. These two populations were expected to have distinct coadapted gene complexes, and the microsatellite analyses confirmed that the Auke Creek and Pillar Creek pink salmon populations differ genetically. These differences are consistent with previous observations that populations of pink salmon diverge over large geographic distances (e.g., Gharrett et al. 1988, Noll et al. 2001, Hawkins et al. 2002).

\section{Survival and Straying in even-and odd-broodyears}

A reduction in survival is the most direct indication of outbreeding depressive effects of hybridization. By examining the returns in both the $F_{1}$ and $F_{2}$ generations, it is possible to distinguish between epistatic or non-epistatic effects on outbreeding depression. The return rates for hybrids and controls were similar for the even-broodyear $F_{1}$ fish, consistent with the survival reported for $F_{1}$ hybrids between even- and odd-broodyear pink salmon (Gharrett \& Smoker 1991, Gharrett et al. 1999). In a somewhat similar experiment, Bams (1976) released first-generation hybrid and transplanted (from the Kakweieken River in B.C., Canada) pink salmon fry from Tsolum River/Headquarters Creek, about $146 \mathrm{~km}$ away; no control release was possible. Both the hybrids and 
transplants had similar survivals, as measured by recoveries in the commercial fishery. However, many fewer transplants than hybrid native/transplanted salmon negotiated their way about $24 \mathrm{~km}$ up the Tsolum River to the release site, suggesting that terminal homing may have a genetic basis.

In contrast to the even-broodyear, the return rate of $\mathrm{F}_{1}$ control fish exceeded that of the hybrids in the odd-broodyear. This is the first of the Auke Creek pink salmon outbreeding depression experiments that demonstrated a reduced survival in $\mathrm{F}_{1}$ hybrids and suggests that non-epistatic effects can contribute to overall survival. For the crosses reported here, developmental characters were also examined (Wang ${ }^{5}$, in preparation). In those studies, timing of mid-hatch was influenced by non-epistatic effects in the first generation. The idea that different genetic mechanisms may have evolved in the two broodyears is consistent with large genetic differences observed between odd- and evenbroodlines of pink salmon (e.g. Aspinwall 1974, McGregor 1982). In fact, little similarity in the distribution of mtDNA variable sites was observed between the evenand odd-broodlines of pink salmon (Churikov et al. 2001), which may reflect differences in postglacial recolonizations of the two broodyears (Churikov \& Gharrett 2002).

Both the even- and odd-broodline $\mathrm{F}_{2}$ hybrids between Pillar Creek and Auke Creek pink salmon had reduced survivals relative to control fish, suggesting that outbreeding depression results from the disruption of coadapted, epistatically-acting gene complexes. These results are consistent with the reduced survival of $F_{2}$ pink salmon

\footnotetext{
${ }^{5}$ Wang, I.A., W.W. Smoker \& A.J. Gharrett. Evidence of outbreeding depression through differences in development rates of pink salmon hybrids. Proceedings of the Northeast Pacific Pink and Chum Salmon Workshop, March 3-5, 1999, Juneau, Alaska. National Marine Fisheries Service, 11305 Glacier Hwy., Juneau, AK 99802 . Cited by permission.
} 
hybrids between even- and odd-broodyear pink salmon at Auke Creek (Gharrett \& Smoker 1991, Gharrett et al. 1999).

Other factors that could have influenced these results include interannual variation and incomplete control over culture conditions. Natural populations experience year-toyear environmental variation. These experiments sampled only two environmental sequences and it is possible that the environmental conditions sampled in our experiments fortuitously favored one group over the other. Fluctuating environmental differences are difficult to assess because only one set of environmental experiences can be observed at a time. In addition, it is possible that subtle incubation differences or marking effects may have influenced the differences in survival. It is unlikely, however, that either of these factors produced the primary effects observed as outbreeding depression because every pink salmon hybridization experiment performed at Auke Creek has yielded similar results (Gharrett \& Smoker 1991, Gharrett et al. 1999).

The differences observed in the survivals of wild and cultured fish are not uncommon (e.g. Miller 1953, Bachman 1984). The reasons for the differences may include the effects of fin excisions, the contribution of uncounted fry derived from intertidal spawning to returns of wild salmon, or delayed mortality in cultured fish resulting from culture conditions.

The small number of experimental fish recovered at Waydelich Creek suggests that, at least in some instances, the straying rate of pink salmon is low. The number of hybrid strays is higher than the number of control strays, but the total number of strays each year was less than 5 and is not statistically significant. Local straying does not 
account for survival differences. The straying rates observed in experimental fish were all less than a point estimate (2.8\%) of straying of native Auke Creek fish within 10km made from observations of otolith-marked fish ${ }^{6}$, but were similar to estimates (less than 1\%) made using a genetic marker (Gharrett et al. 2001).

Failure to observe differences in straying rates of $F_{1}$ hybrids and controls is consistent with Smoker \& Thrower (1995), who did not observe increased straying for either transplanted or hybrid chum salmon compared to native fish. However, in a transplantation study (Bams 1976), more $F_{1}$ pink salmon hybrids between native and transplanted fish were able to navigate $24 \mathrm{~km}$ up the natal river to the release site than transplanted fish. It is difficult to compare these experiments because they used different kinds of crosses and evaluated homing ability differently. Moreover, neither Bams (1976) nor Smoker \& Thrower (1995) followed the fish into the $F_{2}$ generation where outbreeding depression might be expected.

\section{Inbreeding in even- and odd-broodyears}

Because the broodstock for the $\mathrm{F}_{2}$ generation derived from a limited number of parents, the possibility existed that a disproportionate number of full- or half-sib matings might have been included in the experiment, which would increase inbreeding. A loss of genetic diversity due to inbreeding can decrease fitness if essential alleles are lost and deleterious recessive alleles are expressed (Nevo et al 1986, Emlen 1991) and might

\footnotetext{
${ }^{6}$ Mortensen, D., A. Wertheimer, J. Maselko \& S. Taylor. 2000. Survival and straying of pink salmon using recoveries of coded-wire tags and thermally induced otolith marks. Feature article, AFSC Research Activities quarterly report for July-Aug-Sept 2000. Alaska Fisheries Science Center, National Marine Fisheries Service, NOAA.
} 
mask depressive effects due to outbreeding. The inbreeding coefficients for the $F_{2}$ experiments were of the same order of magnitude as would be expected from random breeding; and fortuitously, the hybrid broodstocks had slightly lower inbreeding coefficients than the control broodstocks. Inbreeding was not increased by our choice of broodstock for this study, and it is unlikely that the reduced survival in the $\mathrm{F}_{2}$ hybrids resulted from inbreeding.

\section{Variance in family size of even-broodyears}

Observations of variability in family size and nonrandom marine survival in Pacific salmon populations (Simon et al. 1986, Geiger et al. 1997, Hard et al. 2000) suggest that certain combinations of genotypes resulting from epistatic relationships among genes may cause some individuals to have higher fitness in some environments, but these same combinations may not be favorable as conditions change. If, by chance, an $\mathrm{F}_{2}$ family receives a favorable set of alleles and has a greater return, its offspring may contribute disproportionately to the return and subsequent production. If family size variability increases, the few successful families may not be the most fit in subsequent generations, thereby extending the effects of outbreeding depression to additional generations. In this experiment, more families completely failed and a few families produced more offspring than predicted by the Poisson frequency distribution for both hybrids and controls in the even-broodyear returns; in aggregate, the overall distribution was overdispersed. However, our results suggest that an increase in variability of family size does not account for the decrease in survival seen in the hybrid fish. The relatively small number 
of $\mathrm{F}_{2}$ returns in the even-broodyears of this study may have provided insufficient power to detect small differences in the variability of family size.

\section{Conclusion}

Hybrids between two spatially separated Pacific salmon populations exhibited reduced survival due to outbreeding depression, and evidence of both epistatic and non-epistatic effects was observed. It does not appear that a decreased local homing ability or increased variability in family size accounted for the decrease in hybrid survival. Whether due to non-epistatic or epistatic effects, the decrease in hybrid survival could jeopardize biodiversity of wild stocks if repeated introductions are made. Small, onetime introductions may be of minor concern because natural selection might be expected to remove maladapted genotypes rapidly from a population; however, repeated introductions or development of non-local hatchery brood stocks have the potential to decrease productivity in local wild streams. The possibility of outbreeding depression suggests that broodstocks should be developed from locally adapted natural populations and that salmon managers should consider the potentially detrimental effects of transplanting stocks from one hatchery to another. 


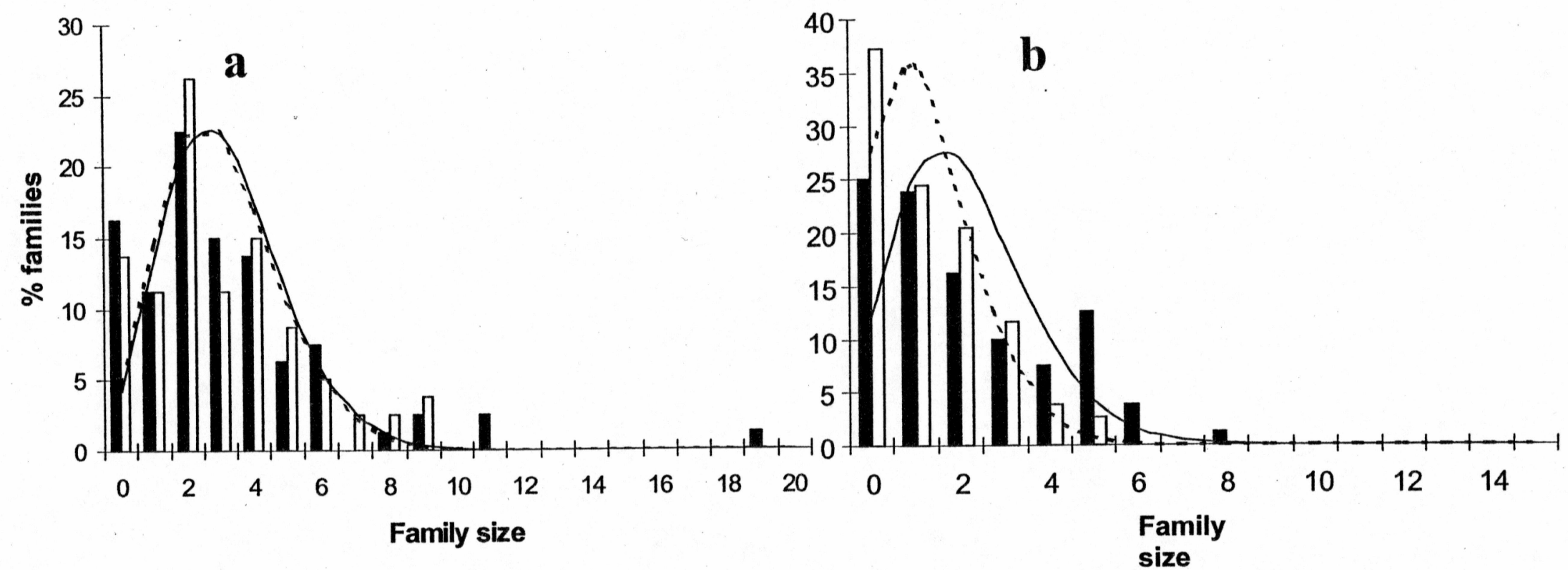

Figure 1. Individual family sizes for even-broodyear $\mathrm{F}_{1}$ and $\mathrm{F}_{2}$ pink salmon returns to Auke Creek. Vertical bars show the observed distribution of offspring; filled bars are control distributions and open bars are hybrid distributions. The curves show the Poisson distribution with the same mean as the observed family size; solid lines are control distributions and dashed lines are hybrid distributions. (a) $1998 \mathrm{~F}_{1}$ returns. Neither the distribution of the control $(\mathrm{p}<0.001)$ nor the hybrid ( $\left.\mathrm{p}<0.01\right)$ samples fit a Poisson distribution (William's corrected $G$-test; Sokal and Rohlf 1995). (b) $2000 \mathrm{~F}_{2}$ returns. The distribution of the control samples did not fit a Poisson distribution $(\mathrm{p}<0.0001)$. The hybrid fit to a Poisson distribution was nearly significant $(\mathrm{p}=0.0505)$ 
Table 1. Number of fry and returning adults for $\mathrm{F}_{1}$ and $\mathrm{F}_{2}$ pink salmon controls (Auke Creek parentage) and hybrids (Auke Creek by Pillar Creek). If their origin could not be determined with microsatellite allele analysis, returning fish with indistinct marks were counted as hybrids. P-values for testing differences in return rates (survival at sea) between hybrids and controls are from log-likelihood ratio tests (Sokal and Rohlf 1995). Estimates of wild releases and returns (Auke Creek) are from annual counts of fry and adults ${ }^{\mathrm{d}}$.

\begin{tabular}{|c|c|c|c|c|c|c|c|c|c|c|c|}
\hline \multirow[b]{2}{*}{ Brood- } & & \multirow[b]{2}{*}{ Fry } & \multicolumn{2}{|l|}{ Control } & \multicolumn{3}{|c|}{ Hybrid } & \multirow[b]{2}{*}{$\mathrm{p}$} & \multicolumn{3}{|c|}{ Wild } \\
\hline & & & Adult & $\%$ & Fry & Adult & $\%$ & & Fry & Adult & $\%$ \\
\hline year & & released & returns & returns & released & returns & returns & (G-test) & released & returns & returns \\
\hline 1996 & $\overline{F_{1}}$ & 19912 & 284 & 1.43 & 20852 & $294^{\mathrm{a}}$ & 1.41 & 0.6774 & 31092 & 2267 & 7.29 \\
\hline 1997 & $\mathrm{~F}_{1}$ & 19918 & 1023 & 5.14 & 19916 & $731^{b}$ & 3.67 & $<0.0001$ & 60785 & 28128 & 46.3 \\
\hline 1998 & $\mathrm{~F}_{2}$ & 20050 & 176 & 0.88 & 20024 & 108 & 0.54 & $<0.0001$ & 53535 & 2181 & 4.07 \\
\hline 1999 & $\mathrm{~F}_{2}$ & 20000 & 254 & 1.27 & 20000 & $192^{\mathrm{c}}$ & 0.96 & 0.0033 & 132075 & 7859 & 5.95 \\
\hline
\end{tabular}

${ }^{\mathrm{a}}$ Includes 2 fish with indistinct marks.

${ }^{\mathrm{b}}$ Includes 25 fish with indistinct marks.

${ }^{\mathrm{c}}$ Includes 18 fish with indistinct marks.

${ }^{\mathrm{d}}$ Taylor, S.G. \& J.L. Lum. 2002. Annual report Auke creek weir 2001: Operations, fish counts, and historical summaries.

Unpublished report 37 p. National Marine Fisheries Service. Auke Bay Laboratory, 11305 Glacier Highway, Juneau, Alaska 99801-8626. 
Table 2. Number of adult pink salmon recovered at Waydelich Creek. If their origin could not be determined with microsatellite parentage analysis, returning fish with incomplete fin excisions were counted as hybrids.

$$
\text { Control Hybrid }
$$

\begin{tabular}{|c|c|c|c|c|c|c|}
\hline & & & & & & \\
\hline Brood- & Total & Number & $\%$ & Total & Number & $\%$ \\
\hline year & returns & captured & captured & returns & captured & Captured \\
\hline 1996 & $\overline{284}$ & $\overline{1}$ & $\overline{0.35}$ & 292 & 3 & 1.03 \\
\hline 1997 & 1023 & 0 & 0 & 706 & 1 & 0.14 \\
\hline 1998 & 172 & 1 & 0.58 & 104 & 2 & 1.92 \\
\hline $1999 \quad F_{2}$ & 254 & 1 & 0.39 & 192 & $4^{a}$ & 2.08 \\
\hline
\end{tabular}

${ }^{a}$ Includes 2 fish with indistinct marks. 


\section{References Cited}

Aspinwall, N. 1974. Genetic analysis of North American populations of the pink salmon, Oncorhynchus gorbuscha, possible evidence for the neutral mutationrandom drift hypothesis. Evolution 28: 295-305.

Bachman, R.A. 1984. Foraging behavior of free-ranging wild and hatchery brown trout in a stream. Trans. Am. Fish. Soc. 113: 1-32.

Bams, R.A. 1976. Survival and propensity for homing as affected by presence or absence of locally adapted paternal genes in two transplanted populations of pink salmon (Oncorhynchus gorbuscha). J. Fish. Res. Board Can. 33: 2716-2725.

Banks, M.A., M.S. Blouin, B.B. Baldwin, V.K. Rashbrook, H.A. Fitzgerald, S.M. Blankenship \& D. Hedgecock. 1999. Isolation and inheritance of novel microsatellites in chinook salmon (Oncorhynchus tshawytscha). J. Hered. 90: 281-288.

Brncic, D. 1954. Heterosis and the integration of the genotype in geographic populations of Drosophila pseudoobscura. Genetics 39: 77-88.

Campton, D.E. 1995. Genetic effects of hatchery fish on wild populations of Pacific salmon and steelhead: What do we really know? Am. Fish. Soc. Symp. 15: 337353.

Carvalho, G.R. 1993. Evolutionary aspects of fish distribution: genetic variability and adaptation. J. Fish Biol. 43(Suppl. A): 53-73. 
Churikov, D. \& A.J. Gharrett. 2002. Comparative phylogeography of the two pink salmon broodlines: an analysis based on mitochondrial DNA genealogy. Mol. Ecol. 11: 1077-1101.

Churikov, D., M. Matsuoka, X. Luan, A.K. Gray, VL.A. Brykov \& A.J. Gharrett. 2001. Assessment of concordance among genealogical reconstructions from various mtDNA segments in three species of Pacific salmon (genus Oncorhynchus). Mol. Ecol. 10: 2329-2339.

Crow, J.F. \& M. Kimura. 1970. An introduction to population genetics theory. Harper and Row Publishers, New York. 591 pp.

Crow, J. \& N.E. Morton. 1955. Measurement of gene frequency drift in small populations. Evolution 9: 202-214.

Danzmann, R.G. 1997. PROBMAX: A computer program for assigning unknown parentage in pedigree analysis from known genotypic pools of parents and progeny. J. Hered. 88: 333.

Danzmann, R.G., T.R. Jackson \& M.M. Ferguson. 1999. Epistasis in allelic expression at upper temperature tolerance QTL in rainbow trout. Aquaculture 173: 45-58.

Dobzhansky, T. 1948. Genetics of natural populations XVII. Experiments on chromosomes of Drosophila pseudoobscura from different geographic regions. Genetics 33: 588-602.

Dobzhansky, T. 1950. Genetics of natural populations XIX. Origin of heterosis through natural selection in populations of Drosophila pseudoobscura. Genetics 35: 288302. 
Emlen, J.M. 1991. Heterosis and outbreeding depression: a multilocus model and an application to salmon production. Fish. Res. 12: 187-212.

Estoup, A., K. Gharbi, M. SanCristobal, C. Chevalet, P. Haffray \& R. Guyomard. 1998. Parentage assignment using microsatellites in turbot (Scophthalmus maximus) and rainbow trout (Oncorhynchus mykiss) hatchery populations. Can. J. Fish. Aquat. Sci. 55: 715-725.

Falconer, D.S. \& T.F.C. Mackay. 1996. Introduction to Quantitative Genetics. 4th ed. Longman Group Ltd., Essex, England. 464 pp.

Geiger, H.H., W.W. Smoker, L.A. Zhivotovsky \& A.J. Gharrett. 1997. Variability of family size and marine survival in pink salmon (Oncorhynchus gorbuscha) has implications for conservation biology and human use. Can. J. Fish. Aquat. Sci. 54: 2684-2690.

Gharrett, A.J. \& W.W. Smoker. 1991. Two generations of hybrids between even- and odd-year pink salmon (Oncorhynchus gorbuscha): a test for outbreeding depression? Can. J. Fish. Aquat. Sci. 48: 1744-1749.

Gharrett, A.J., S. Lane, A.J. McGregor \& S.G. Taylor. 2001. Use of a genetic marker to examine genetic interaction among subpopulations of pink salmon (Oncorhynchus gorbuscha). Genetica 111: 259-267.

Gharrett, A.J., W.W. Smoker, R.R. Reisenbichler \& S.G. Taylor. 1999. Outbreeding depression in hybrids between odd- and even-broodyear pink salmon. Aquaculture 173: 117-129. 
Gharrett, A.J., C. Smoot, A.J. McGregor \& P.B. Holmes. 1988. Genetic relationships of even-year northwestern Alaskan pink salmon. Trans. Am. Fish. Soc. 117: 536545.

Gordon, H. \& M. Gordon. 1957. Maintenance of polymorphism by potentially injurious genes in eight natural populations of the platyfish, Xiphophorus maculatus. J. Genet. 55: 1-44.

Hard, J.J. 1995. Genetic monitoring of life-history characters in salmon supplementation: Problems and opportunities. Am. Fish. Soc. Symp. 15: 212225.

Hard, J.J., L. Connell, W.K. Hershberger \& L.W. Harrell. 2000. Genetic variation in mortality of Chinook salmon during a bloom of the marine alga Heterosigma akashiwo. J. Fish Biol. 56: 1387-1397.

Hawkins, S.L., N.V. Varnavskaya, E.A. Matzak, V.V. Efremov, C.M. Guthrie III, R.L. Wilmot, H. Mayama, F. Yamazaki \& A.J. Gharrett. 2002. Population structure of odd-broodline Asian pink salmon and its contrast to the even-broodline structure. J. Fish Biol. 60: 370-388.

Hemmingsen, A.R., R.A. Holt, R.D. Ewing \& J.D. McIntyre. 1986. Susceptibility of progeny from crosses among three stocks of coho salmon to infection by Ceratomyxa shasta. Trans. Am. Fish. Soc. 115: 492-495.

Hindar, K., N. Ryman \& F. Utter. 1991. Genetic effects of cultured fish on natural fish populations. Can. J. Fish. Aquat. Sci. 48: 945-957. 
King, J.C. 1955. Evidence for the integration of the gene pool from studies of DDT resistance in Drosophila. Cold Spring Harbor Symposium on Quantitative Biology 20: 311-317.

Lane, S., A.J. McGregor, S.G. Taylor, \& A.J. Gharrett. 1990. Genetic marking of an Alaskan pink salmon population, with an evaluation of the mark and the marking process. Am. Fish. Soc. Symp. 7: 395-406.

Leberg, P.L. 1993. Strategies for population reintroduction: Effects of variability. Cons. Biol. 7: 194-199.

Lichatowich, J. 1999. Salmon without rivers: A history of the Pacific salmon crisis. Island Press, Washington, D.C. 317 pp.

Lynch, M. 1991. The genetic interpretation of inbreeding depression and outbreeding depression. Evolution 45: 622-629.

McGregor, A.J. 1982. A biochemical genetic analysis of pink salmon (Oncorhynchus gorbuscha) from selected streams in northern Southeast Alaska. MS Thesis, University of Alaska Juneau, Juneau, AK.

McGregor, A.J., S. Lane, M.A. Thomason, L.A. Zhivotovsky, W.W. Smoker, \& A.J. Gharrett. 1998. Migration timing, a life history trait important in the genetic structure of pink salmon. N. Pac. Anadr. Fish Comm. Bull. 1: 262-273.

Miller, R.B. 1953. Comparative survival of wild and hatchery-reared cutthroat trout in a stream. Trans. Am. Fish. Soc. 83: 120-130.

Nevo, E., R. Noy, B. Lavie, B. Beiles \& S. Muchtar. 1986. Genetic diversity and resistance to marine pollution. Biol. J. Linn. Soc. 29: 139-144. 
Noll, C., N.V. Varnavskaya, E.A. Matzak, S.L. Hawkins, V.V. Midanaya, O.N. Katugin, C. Russell, N.M. Kinas, C.M. Guthrie III, H. Mayama, F. Yamazaki, B.P. Finney \& A.J. Gharrett. 2001. Analysis of contemporary genetic structure of evenbroodyear populations of Asian and western Alaskan pink salmon, Oncorhynchus gorbuscha. Fish. Bull. 99: 123-138.

Olsen, J.B., P. Bentzen \& J.E. Seeb. 1998. Characterization of seven microsatellite loci derived from pink salmon. Mol. Ecol. 7: 1087-1089.

O’Reilly, P., L.C. Hamilton, S.K. McConnell \& J.M. Wright. 1996. Rapid detection of genetic variation in Atlantic salmon (Salmo salar) by PCR multiplexing of dinucleotide and tetranucleotide microsatellites. Can. J. Fish. Aquat. Sci. 53: 2292-2298.

Philipp, D.P. \& J.E. Claussen. 1995. Fitness and performance differences between two stocks of largemouth bass from different river drainages within Illinois. Am. Fish. Soc. Symp. 15: 236-243.

Quinn, T.P. 1993. A review of homing and straying of wild and hatchery-produced salmon. Fish. Res. 18: 29-44.

Raymond, M. \& F. Rousset. 1995. An exact test for population differentiation. Evolution 49: 1280-1283.

Roff, D.A. \& P. Bentzen. 1989. The statistical analysis of mitochondrial DNA polymorphisms: $\chi^{2}$ and the problem of small samples. Mol. Biol. Evol. 6: 539545. 
Seutin, G., B.N. White \& P.T. Boag. 1991. Preservation of avian blood and tissue samples for DNA analyses. Can. J. Zool. 69: 82-90.

Shields, W.M. 1982. Philopatry, Inbreeding, and the Evolution of Sex. State University of New York Press, Albany, NY.

Simon, R.C., J.D. McIntyre \& A.R. Hemmingsen. 1986. Family size and effective population size in a hatchery stock of coho salmon (Oncorynchus kisutch). Can. J. Fish. Aquat. Sci. 43: 2434-2442.

Small, M.P., T.D. Beacham, R.E. Withler \& R. J. Nelson. 1998. Discriminating coho salmon (Oncorhynchus kisutch) populations withing the Fraser River, British Columbia, using microsatellite DNA markers. Mol. Ecol. 7: 141-155.

Smith, C.T., B.F. Koop \& R.J. Nelson. 1998. Isolation and characterization of coho salmon (Oncorhynchus kisutch) microsatellites and their use in other salmonids. Mol. Ecol. 7: 1614-1616.

Smoker, W.W. \& F.P. Thrower. 1995. Homing propensity in transplanted and native chum salmon. Am. Fish. Soc. Symp. 15: 575-576.

Sokal, R.R. \& F.J. Rohlf. 1995. Biometry, $3^{\text {rd }}$ ed. W.H. Freeman and Company, New York. $887 \mathrm{pp}$.

Waldbieser, G.C. \& W.R. Wolters. 1999. Application of polymorphic microsatellite loci in a channel catfish (Ictalurus punctatus) breeding program. J. World Aquacult. Soc. 30: 256-262.

Wallace, B. 1981. Coadaptation revisited. J. Hered. 82: 89-95. 
Winer, B.J. 1971. Statistical principles in experimental design, 2nd ed. McGraw-Hill, New York. 907 p. 


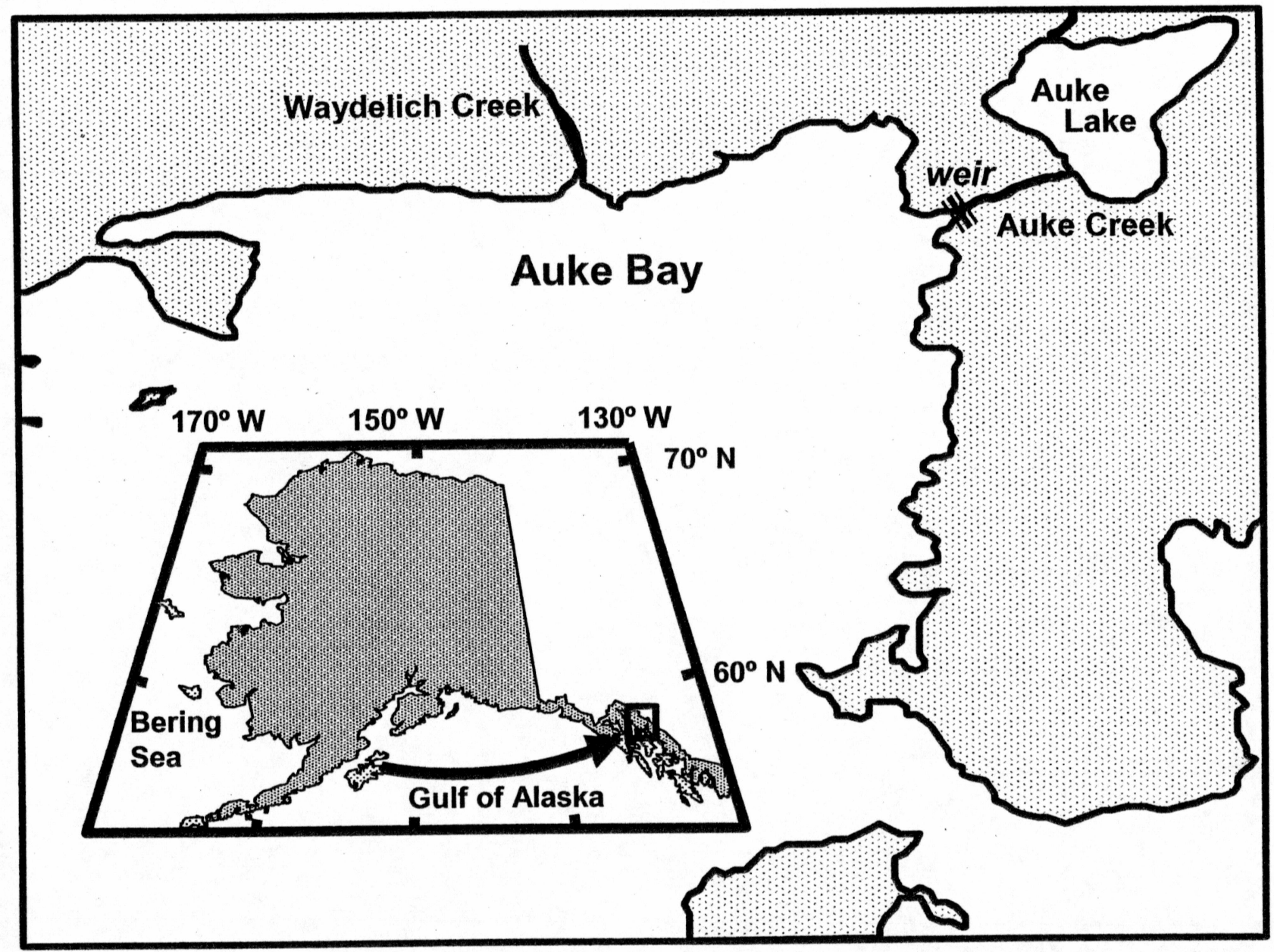

?20

Figure A.1. Map of study area. Salmon returning to Auke Creek, near Juneau, Alaska were the model native population. Males from Pillar Creek, Kodiak, Alaska (great circle distance $1048 \mathrm{~km}$ away) were the model donor population. Nearby (about $1 \mathrm{~km}$ ) Waydelich Creek was routinely seined to collect any possible strays. 


\section{Even-year broodline}

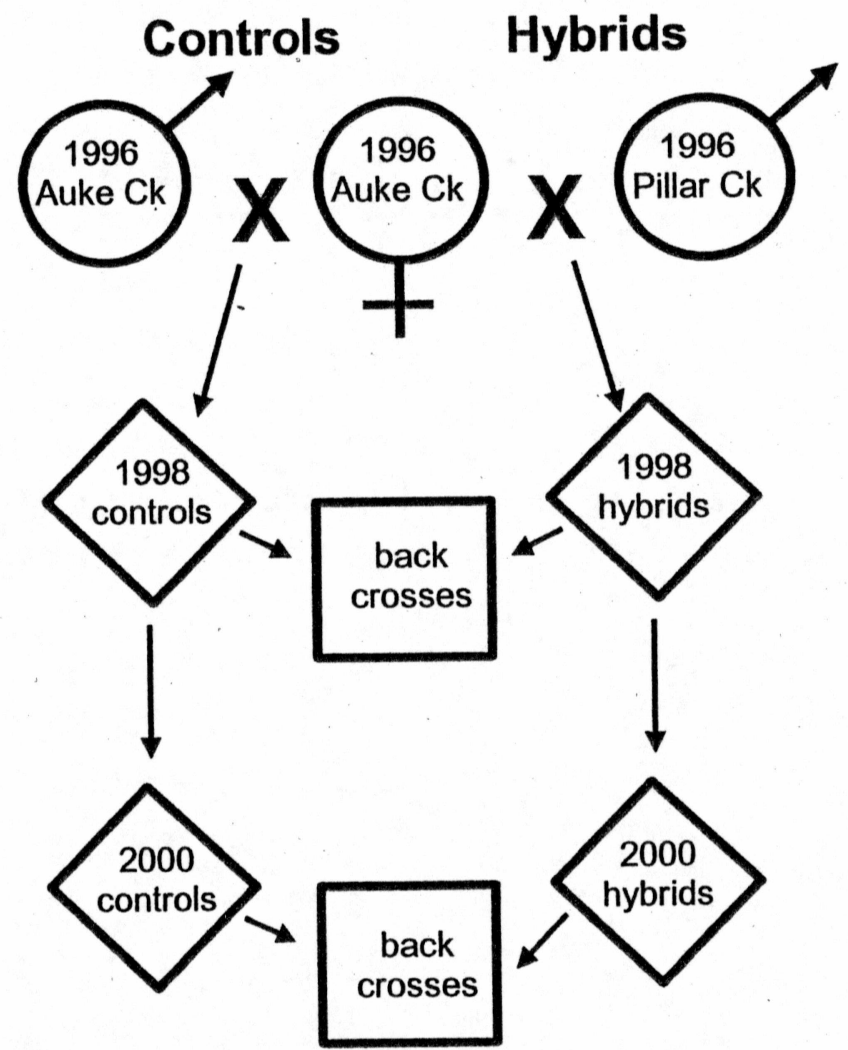

Odd-year broodline
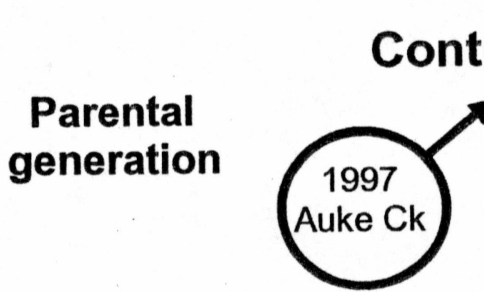

$F_{1}$ generation
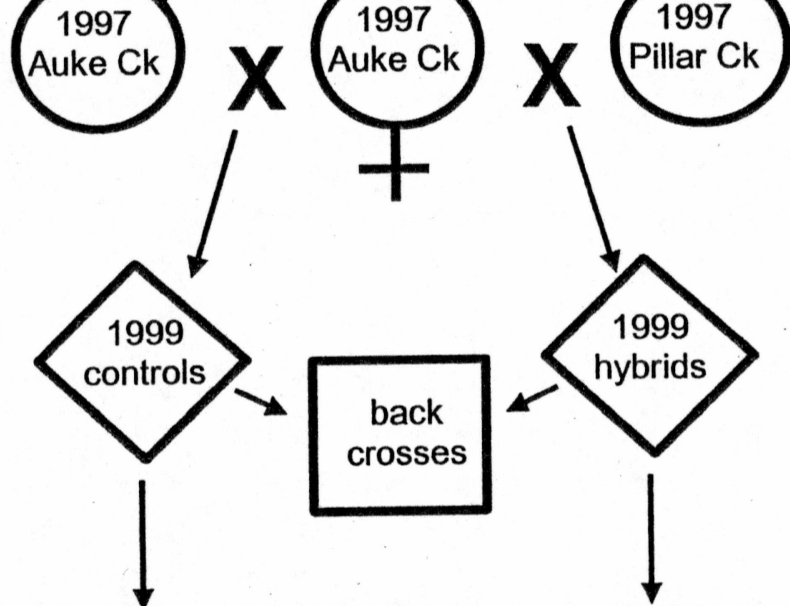

$F_{2}$ generation

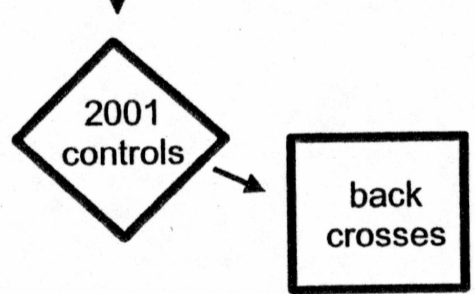

2001

hybrids

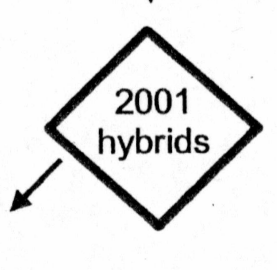

Figure B.1. Replicated incomplete-factorial mating design used for experiments. Though originally intended for other quantitative genetic analyses, the data was adequate to examine family size variability. 
Table C.1. Microsatellite loci used for pink salmon parentage analysis. Samples are Pillar Creek and Auke Creek fish used for breeding experiments in 1996 and 1997.

\begin{tabular}{|c|c|c|c|c|c|}
\hline Locus & Reference & $\begin{array}{l}\text { Primer } \\
\text { sequence }\left(5^{\prime}-3^{\prime}\right)\end{array}$ & $\begin{array}{l}\text { Size } \\
\text { (bp) }\end{array}$ & $\begin{array}{l}\text { No. of } \\
\text { alleles }\end{array}$ & $\begin{array}{l}\text { Sample } \\
\text { size }(N)\end{array}$ \\
\hline \multirow[t]{2}{*}{ Ogo1a } & Olsen et al. 1998 & F: GATCTGGGCCTAAGGGAAAC & $181->400^{\mathrm{a}}$ & $>84$ & 500 \\
\hline & & R: ACTAGCGGTTGGAGAACCC & & & \\
\hline \multirow[t]{2}{*}{ Oki10 } & Smith et al. 1998 & F: GGAGTGCTGGACAGATTGG & $135-325$ & 52 & 502 \\
\hline & & R: CAGCTTTTTACAAATCCTCCTG & & & \\
\hline \multirow[t]{2}{*}{ Oki11 } & Smith et al. 1998 & F: TCTGAGACAGGCAAATGCAC & $76-252$ & 72 & 436 \\
\hline & & R: GTTTTAAACCTCACCATTGAGT & & & \\
\hline \multirow[t]{2}{*}{ Ots 1} & Banks et al. 1999 & F: GGAAAGAGCAGATGTTGTT & $218-256$ & 20 & 478 \\
\hline & & R: TGAAGCAGCAGATAAAGCA & & & \\
\hline \multirow[t]{2}{*}{ Ots 103} & Small et al. 1998 & F: AGGCTCTGGGTCCGTG & $208-497$ & 59 & 500 \\
\hline & & R: GACATAGCGTTCAGCACAG & & & \\
\hline \multirow[t]{2}{*}{ Ssa 197} & O'Reilly et al. & F: GGGTTGAGTAGGGAGGCTTG & $116-208$ & 25 & 477 \\
\hline & 1996 & R: TGGCAGGGATTTGACATAAC & & & \\
\hline
\end{tabular}

${ }^{a}$ Alleles over 400 bp were binned for ease of scoring. 


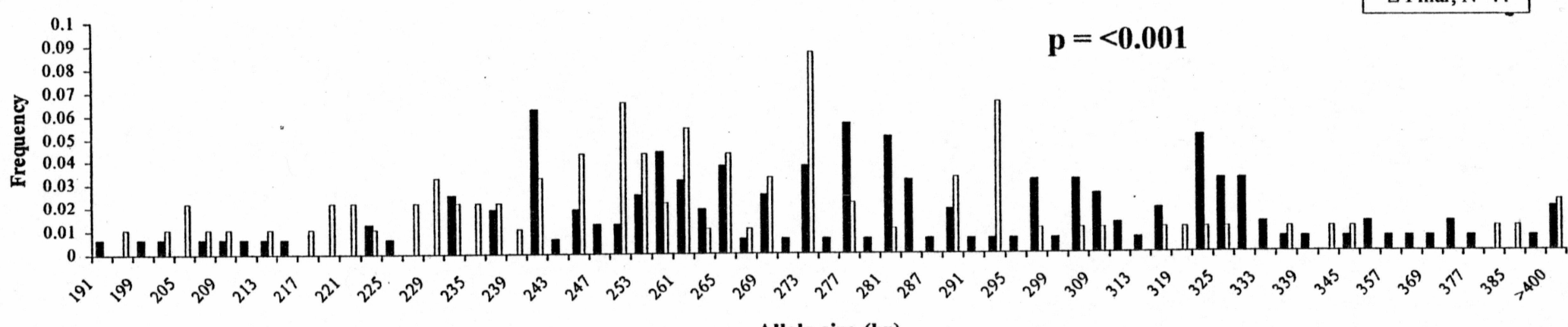

Allele size (bp)

Oki 10

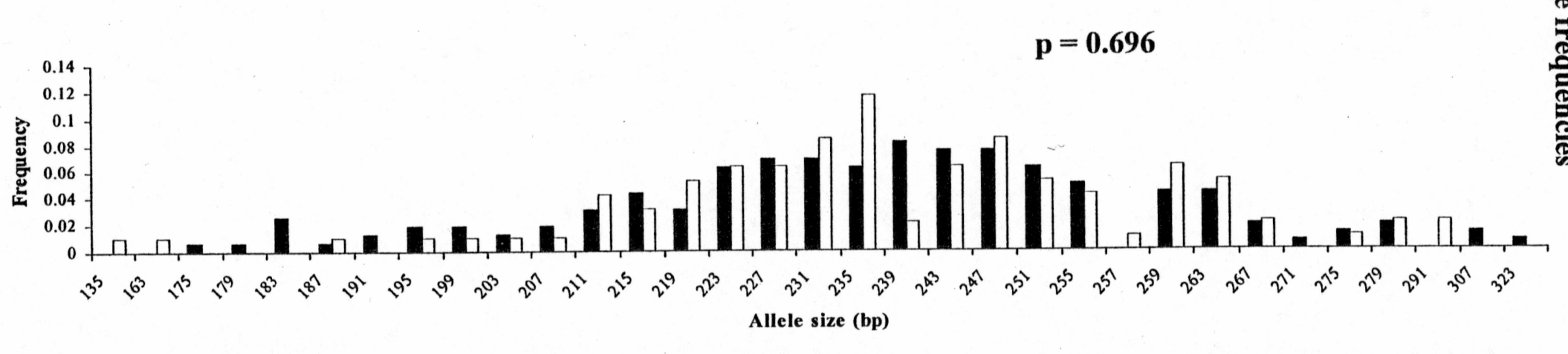

Figure D.1. Homogeneity of allele frequencies at the Ogo1 a and Oki10 microsatellite loci between Auke Creek and Pillar Creek pink salmon used for breeding experiments in 1996. P-values were found using $G$-test statistics and a permutation test $(20,000$ iterations) similar to Roff \& Bentzen (1989). N is the number of fish sampled. Homogeneity tests across all loci revealed significant $(\mathrm{p}<0.0001)$ divergence between Auke and Pillar Creek fish used in 1996. 
Oki 11

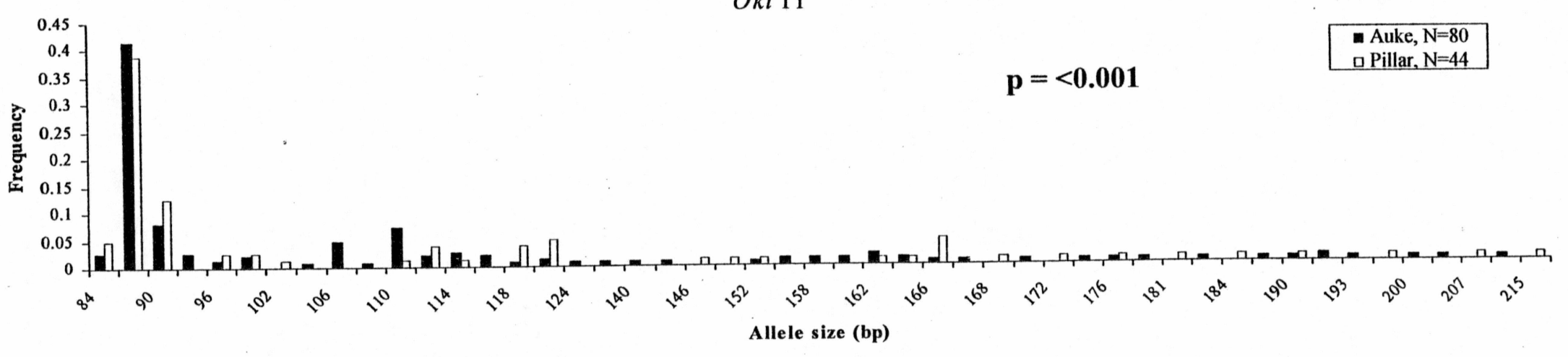

Ots 103

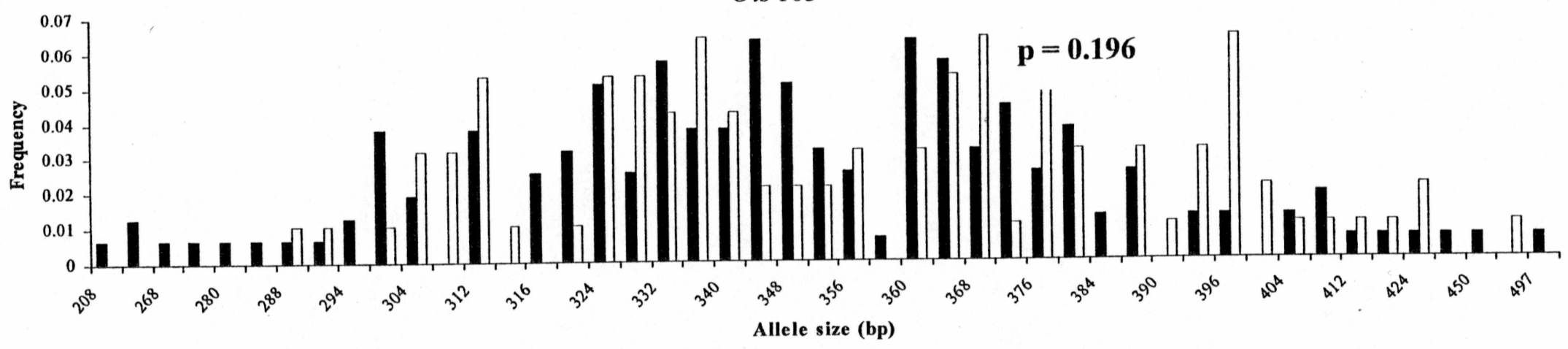

Figure D.2. Homogeneity of allele frequencies at the Oki11 and Ots 103 microsatellite loci between Auke Creek and Pillar Creek pink salmon used for breeding experiments in 1996. P-values were found using $G$-test statistics and a permutation test (20,000 iterations) similar to Roff \& Bentzen (1989). N is the number of fish sampled. Homogeneity tests across all loci revealed significant $(\mathrm{p}<0.0001)$ divergence between Auke and Pillar Creek fish used in 1996. 

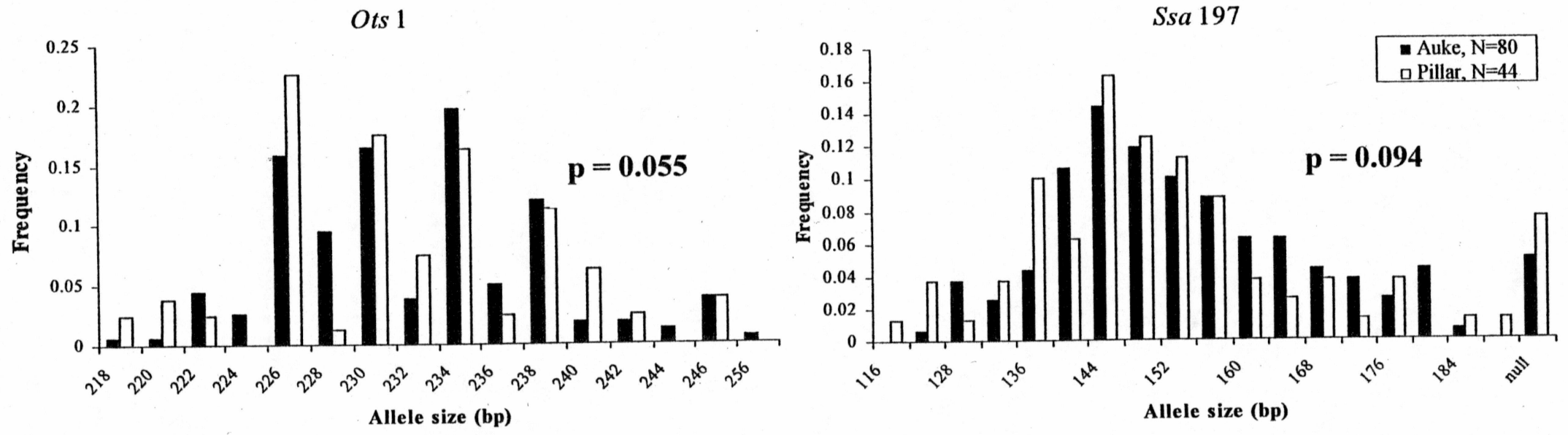

Figure D.3. Homogeneity of allele frequencies at the Ots 1 and Ssa197 microsatellite loci between Auke Creek and Pillar Creek pink salmon used for breeding experiments in 1996. P-values were found using $G$-test statistics and a permutation test (20,000 iterations) similar to Roff \& Bentzen (1989). N is the number of fish sampled. Homogeneity tests across all loci revealed significant $(\mathrm{p}<0.0001)$ divergence between Auke and Pillar Creek fish used in 1996. 
Ogo 1 a

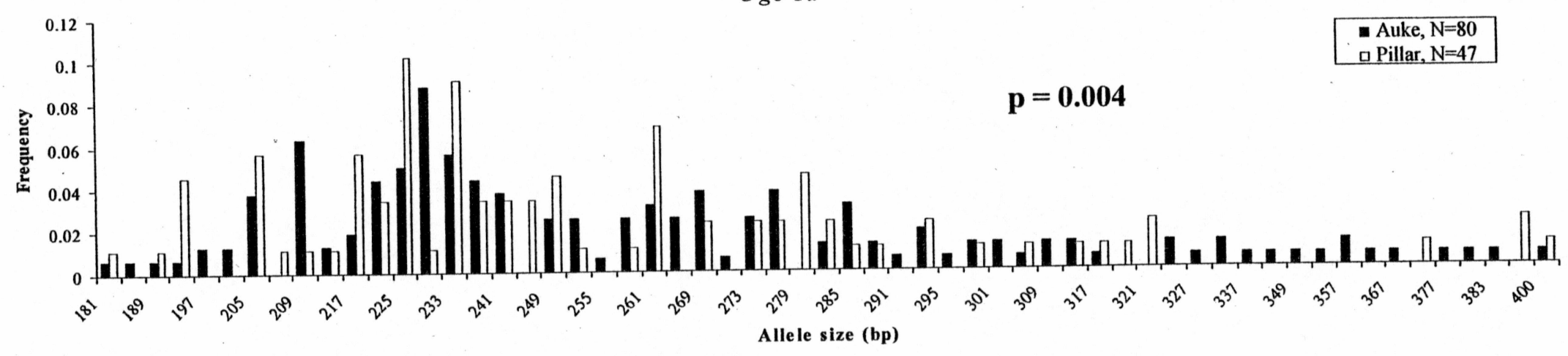

Oki 10

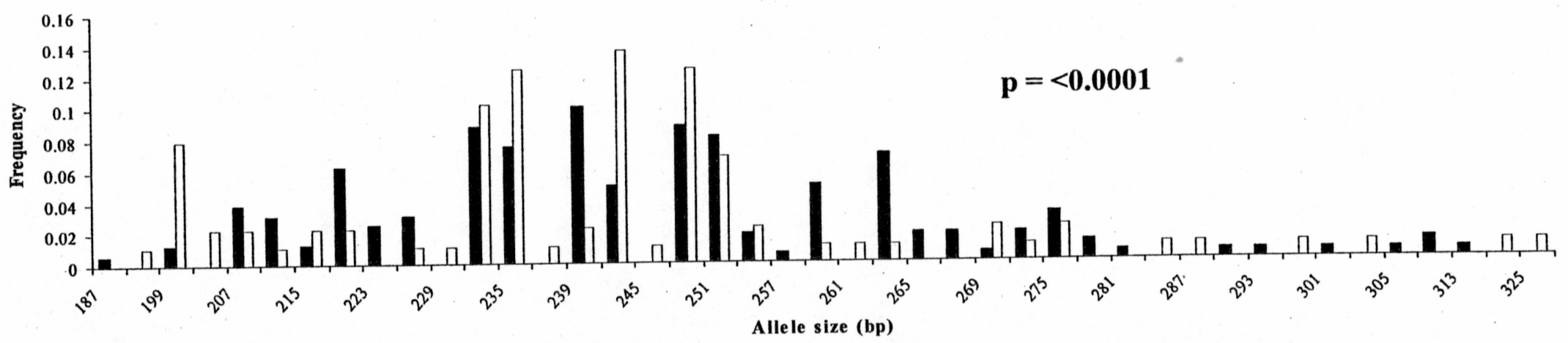

Figure D.4. Homogeneity of allele frequencies at the Ogo1a and Oki10 microsatellite loci between Auke Creek and Pillar Creek pink salmon used for breeding experiments in 1997. P-values were found using $G$-test statistics and a permutation test $(20,000$ iterations) similar to Roff \& Bentzen (1989). N is the number of fish sampled. Homogeneity tests across all loci revealed significant $(\mathrm{p}<0.0001)$ divergence between Auke and Pillar Creek fish used in 1997. 
Oki 11

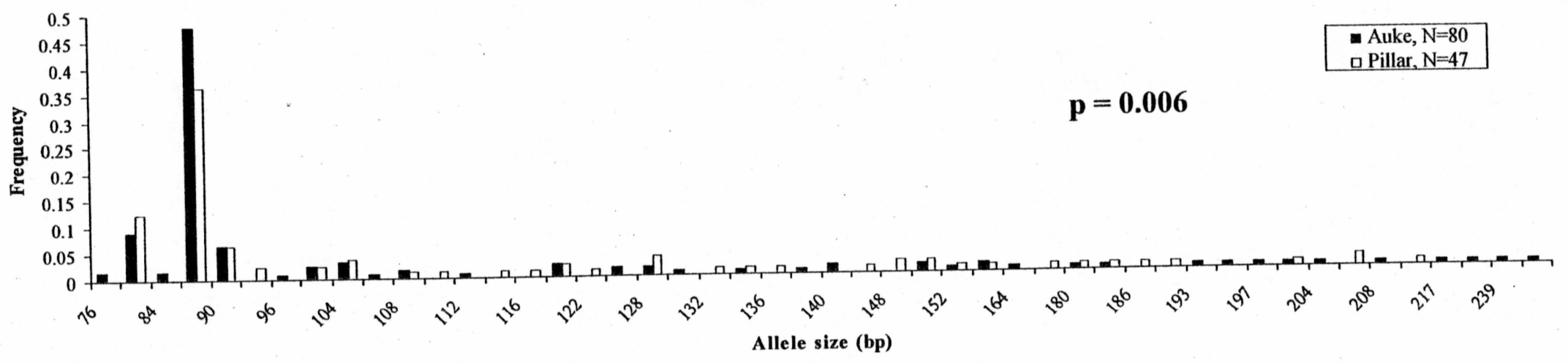

Ots 103

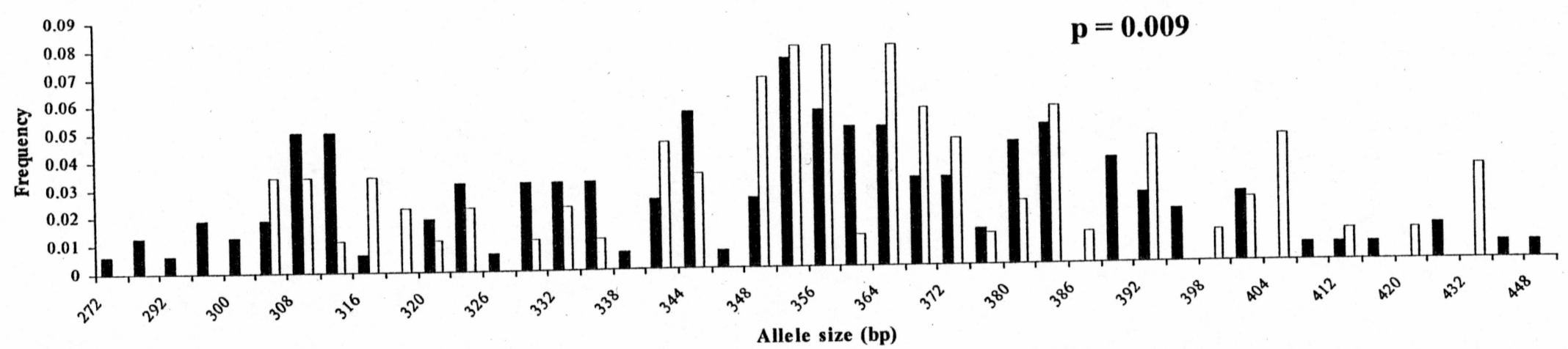

Figure D.5. Homogeneity of allele frequencies at the Oki11 and Ots 103 microsatellite loci between Auke Creek and Pillar Creek pink salmon used for breeding experiments in 1997. P-values were found using $G$-test statistics and a permutation test (20,000 iterations) similar to Roff \& Bentzen (1989). N is the number of fish sampled. Homogeneity tests across all loci revealed significant $(\mathrm{p}<0.0001)$ divergence between Auke and Pillar Creek fish used in 1997. 

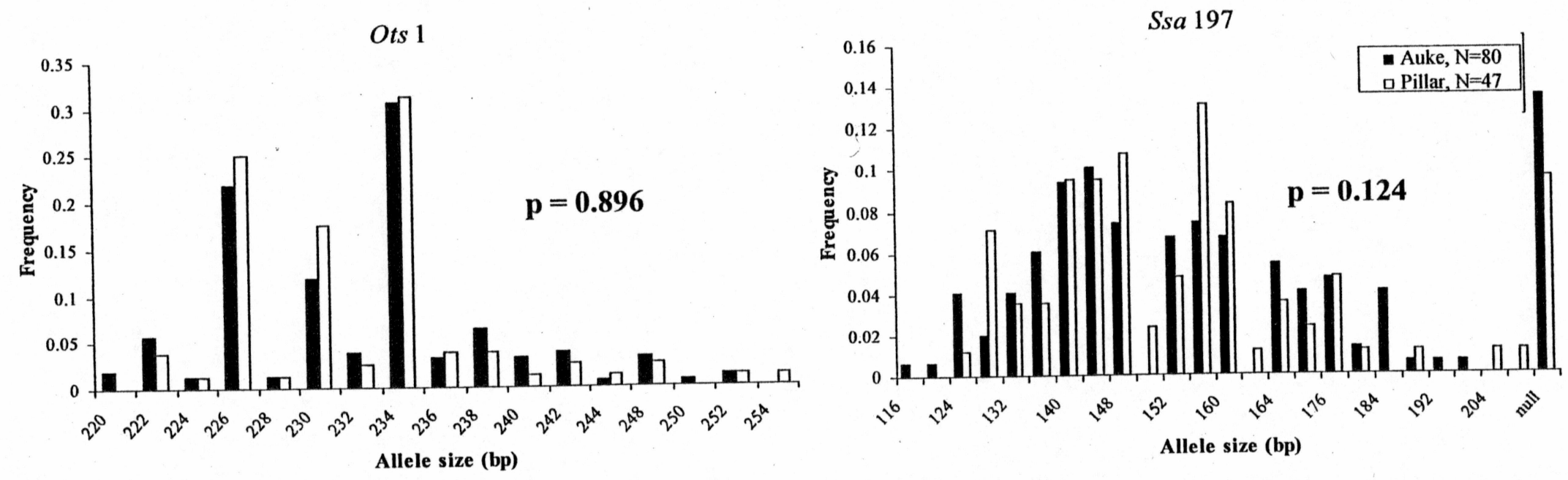

Figure D.6. Homogeneity of allele frequencies at the Ots 1 and Ssa197 microsatellite loci between Auke Creek and Pillar Creek pink salmon used for breeding experiments in 1997. P-values were found using $G$-test statistics and a permutation test (20,000 iterations) similar to Roff \& Bentzen (1989). $N$ is the number of fish sampled. Homogeneity tests across all loci revealed significant $(\mathrm{p}<0.0001)$ divergence between Auke and Pillar Creek fish used in 1997. 


\section{Appendix E: Allele frequencies}

Table E.1. Observed allele frequencies for the Ogola microsatellite locus in Auke and Pillar Creek pink salmon used for breeding experiments in 1996 and 1997.

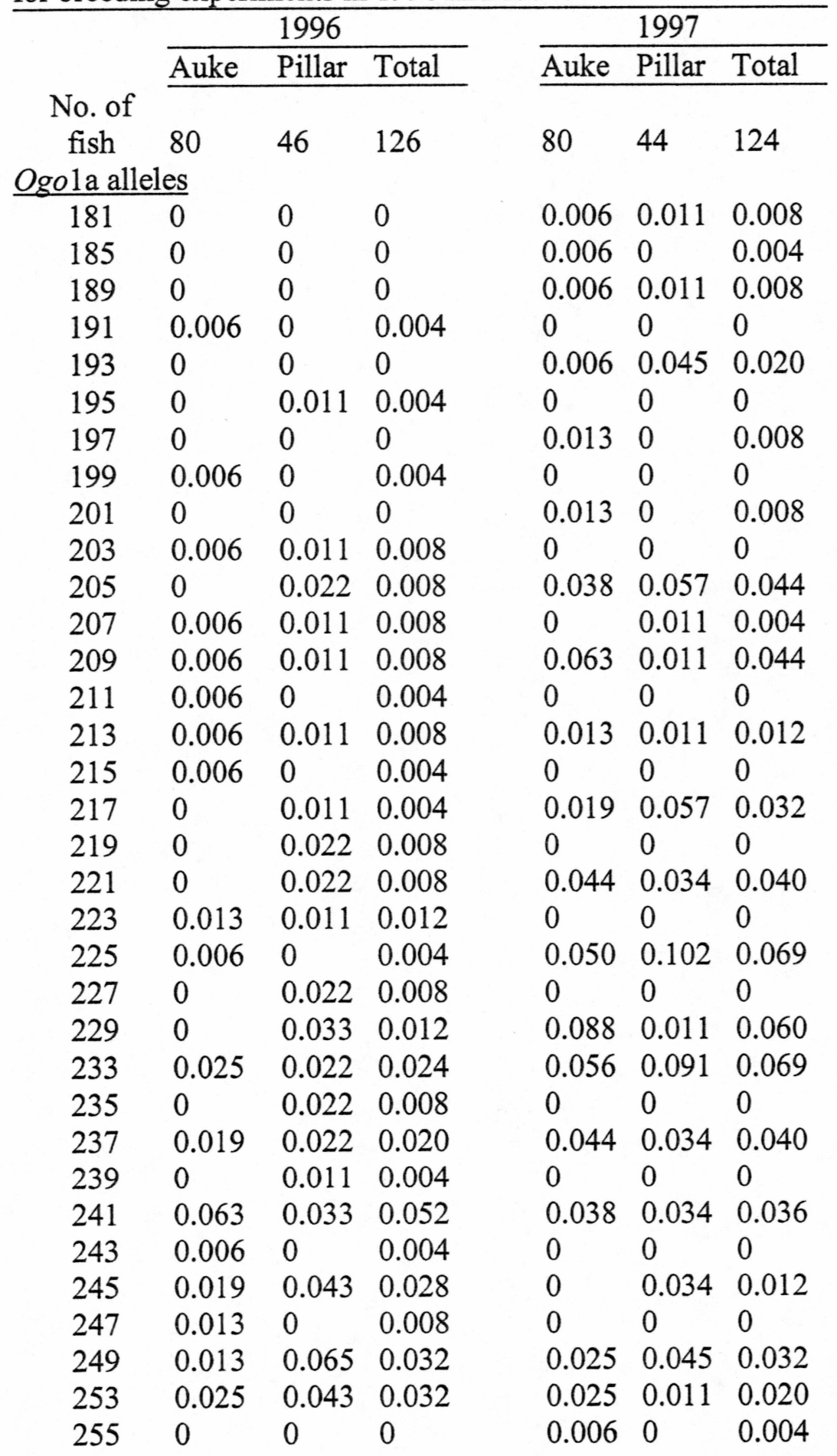


Table E.1. Continued

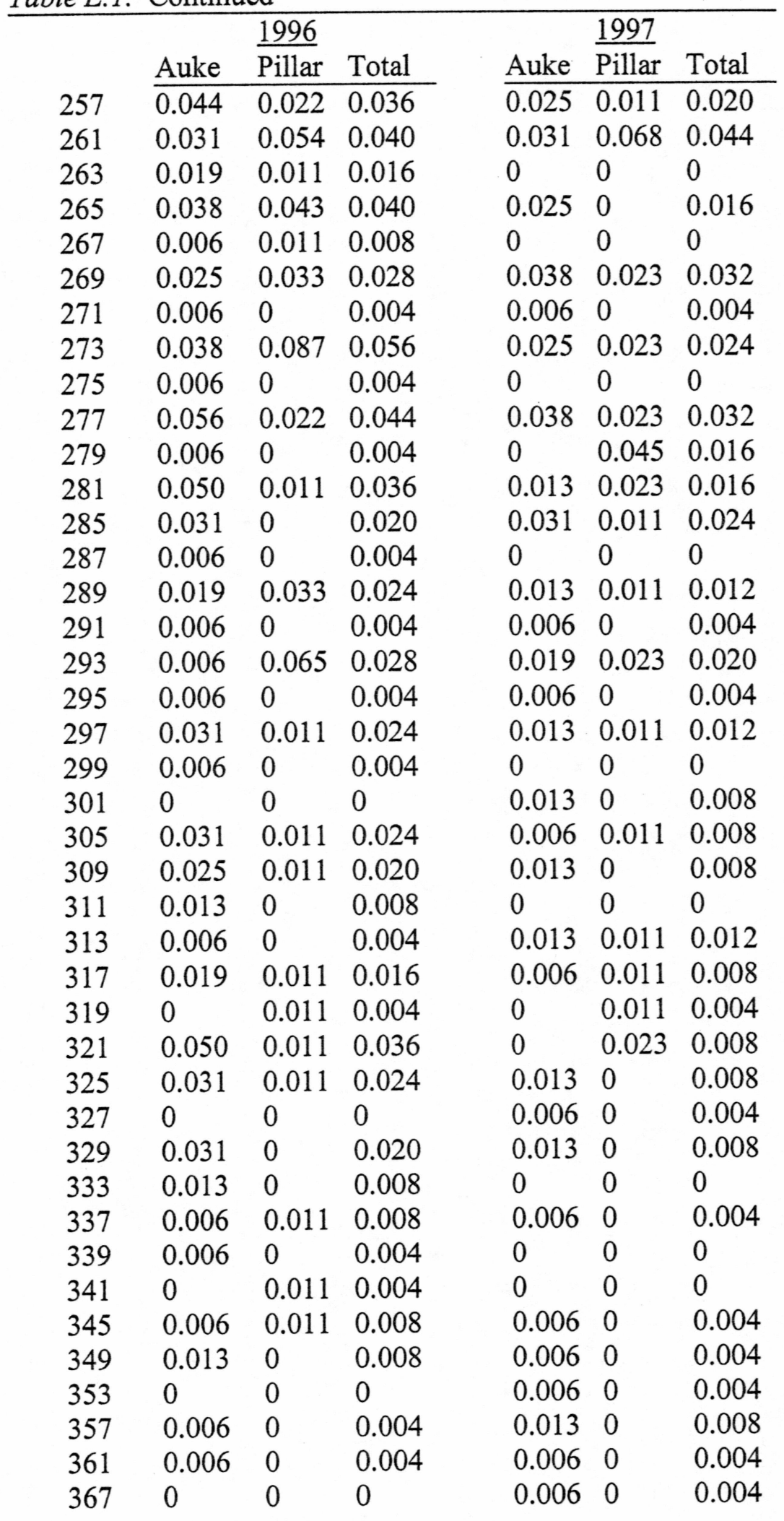


Table E.1. Continued

\begin{tabular}{|c|c|c|c|c|c|c|}
\hline & \multicolumn{3}{|c|}{1996} & \multicolumn{3}{|c|}{$\underline{1997}$} \\
\hline & Auke & Pillar & Total & Auke & $\overline{\text { Pillar }}$ & Total \\
\hline 369 & 0.006 & 0 & 0.004 & 0 & 0.011 & 0.004 \\
\hline 373 & 0.013 & 0 & 0.008 & 0 & 0 & 0 \\
\hline 377 & 0.006 & 0 & 0.004 & 0.006 & 0 & 0.004 \\
\hline 381 & 0 & 0.011 & 0.004 & 0.006 & 0 & 0.004 \\
\hline 383 & 0 & 0 & 0 & 0.006 & 0 & 0.004 \\
\hline 385 & 0 & 0.011 & 0.004 & 0 & 0 & 0 \\
\hline 395 & 0.006 & 0 & 0.004 & 0 & 0 & 0 \\
\hline 399 & 0 & 0 & 0 & 0 & 0.023 & 0.008 \\
\hline$>400$ & 0.019 & 0.022 & 0.020 & 0.006 & 0.011 & 0.008 \\
\hline
\end{tabular}


Table E.2. Observed allele frequencies for the Oki10 microsatellite locus in Auke and Pillar Creek pink salmon used for breeding experiments in 1996 and 1997.

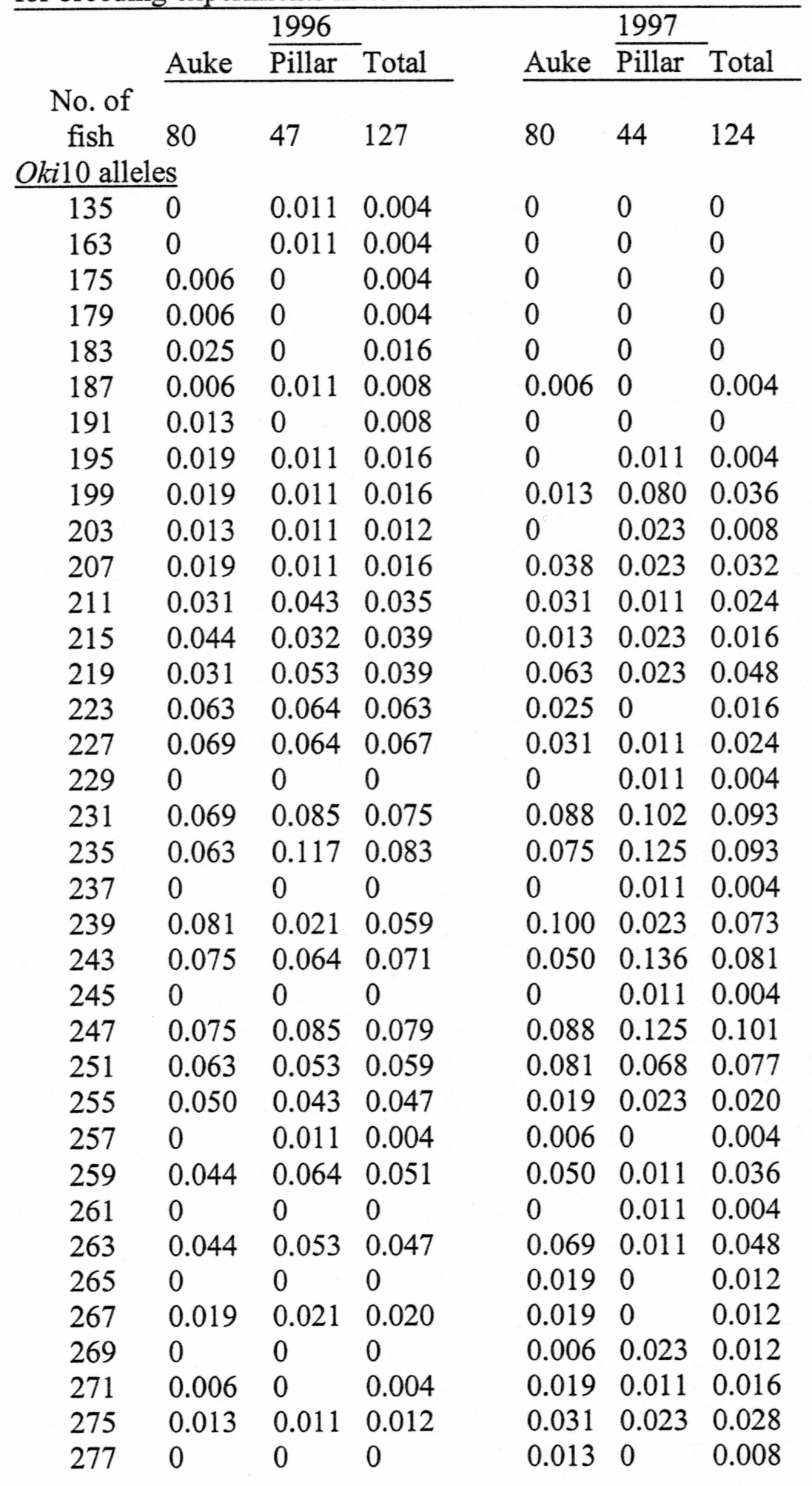


Table E.2. Continued.

\begin{tabular}{|c|c|c|c|c|c|c|}
\hline & \multicolumn{3}{|c|}{1996} & \multicolumn{3}{|c|}{1997} \\
\hline & Auke & $\begin{array}{l}\text { Pillar } \\
\end{array}$ & Total & Auke & Pillar & Total \\
\hline 279 & $\overline{0.019}$ & 0.021 & 0.020 & 0 & 0 & 0 \\
\hline 281 & 0 & 0 & 0 & 0.006 & 0 & 0.004 \\
\hline 285 & 0 & 0 & 0 & 0 & 0.011 & 0.004 \\
\hline 287 & 0 & 0 & 0 & 0 & 0.011 & 0.004 \\
\hline 291 & 0 & 0.021 & 0.008 & 0.006 & 0 & 0.004 \\
\hline 293 & 0 & 0 & 0 & 0.006 & 0 & 0.004 \\
\hline 297 & 0 & 0 & 0 & 0 & 0.011 & 0.004 \\
\hline 301 & 0 & 0 & 0 & 0.006 & 0 & 0.004 \\
\hline 303 & 0 & 0 & 0 & 0 & 0.011 & 0.004 \\
\hline 305 & 0 & 0 & 0 & 0.006 & 0 & 0.004 \\
\hline 307 & 0.013 & 0 & 0.008 & 0 & 0 & 0 \\
\hline 309 & 0 & 0 & 0 & 0.013 & 0 & 0.008 \\
\hline 313 & 0 & 0 & 0 & 0.006 & 0 & 0.004 \\
\hline 321 & 0 & 0 & 0 & 0 & 0.011 & 0.004 \\
\hline 323 & 0.006 & 0 & 0.004 & 0 & 0 & 0 \\
\hline 325 & 0 & 0 & 0 & 0 & 0.011 & 0.004 \\
\hline
\end{tabular}


Table E.3. Observed allele frequencies for the Oki11

microsatellite locus in Auke and Pillar Creek pink salmon used for breeding experiments in 1996 and 1997.

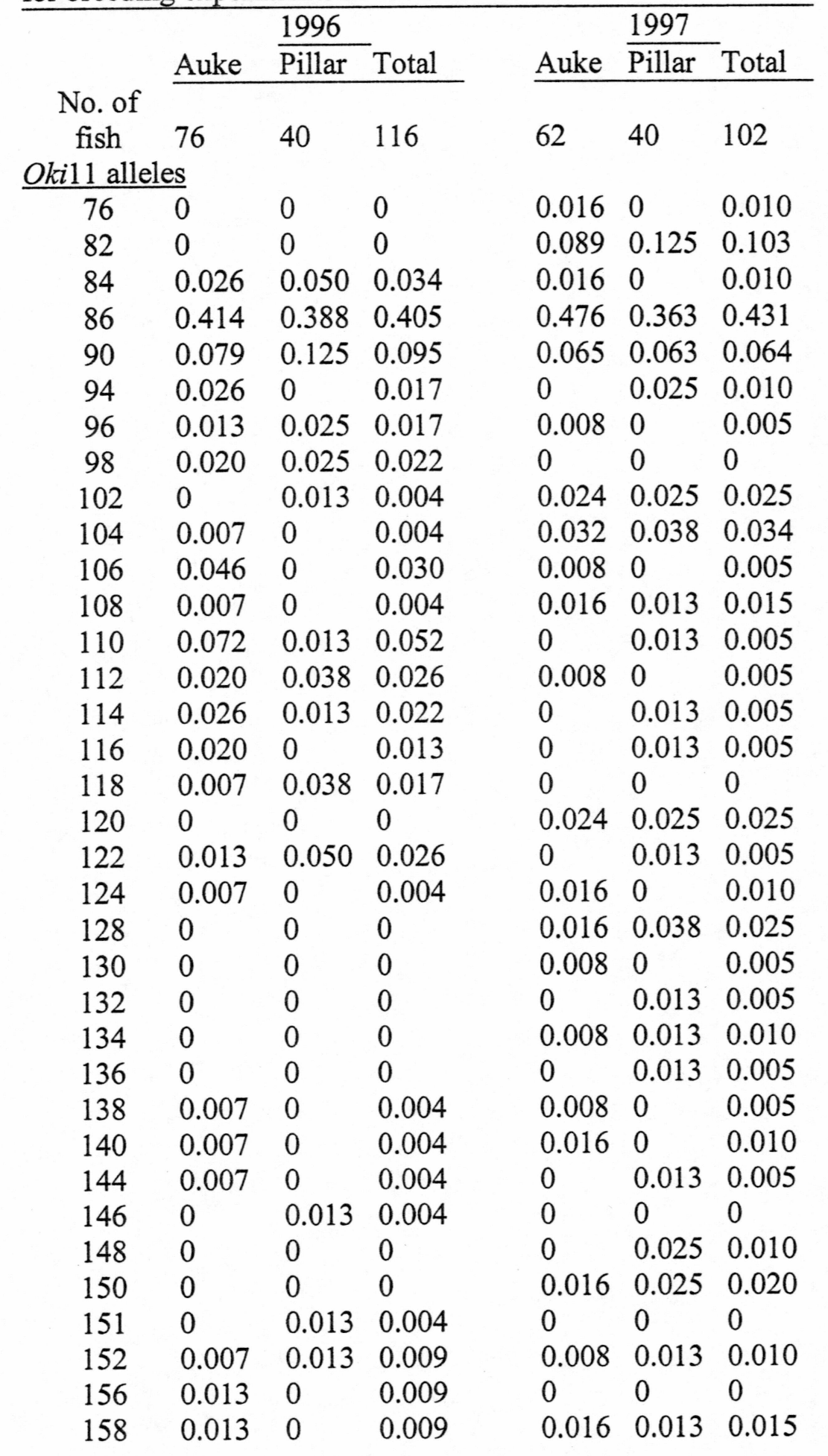


Table E.3. Continued.

\begin{tabular}{|c|c|c|c|c|c|c|}
\hline & & 1996 & & & 1997 & \\
\hline & Auke & Pillar & Total & Auke & Pillar & Total \\
\hline 160 & 0.013 & 0 & 0.009 & 0 & 0 & 0 \\
\hline 162 & 0.020 & 0.013 & 0.017 & 0 & 0 & 0 \\
\hline 164 & 0.013 & 0.013 & 0.013 & 0.008 & 0 & 0.005 \\
\hline 166 & 0.007 & 0.050 & 0.022 & 0 & 0.013 & 0.005 \\
\hline 167 & 0.007 & 0 & 0.004 & 0 & 0 & 0 \\
\hline 168 & 0 & 0.013 & 0.004 & 0 & 0 & 0 \\
\hline 170 & 0.007 & 0 & 0.004 & 0 & 0 & 0 \\
\hline 172 & 0 & 0.013 & 0.004 & 0 & 0 & 0 \\
\hline 174 & 0.007 & 0 & 0.004 & 0 & 0 & 0 \\
\hline 176 & 0.007 & 0.013 & 0.009 & 0 & 0 & 0 \\
\hline 179 & 0.007 & 0 & 0.004 & 0 & 0 & 0 \\
\hline 180 & 0 & 0 & 0 & 0.008 & 0.013 & 0.010 \\
\hline 181 & 0 & 0.013 & 0.004 & 0 & 0 & 0 \\
\hline 182 & 0.007 & 0 & 0.004 & 0 & 0 & 0 \\
\hline 184 & 0 & 0.013 & 0.004 & 0.008 & 0.013 & 0.010 \\
\hline 186 & 0 & 0 & 0 & 0 & 0.013 & 0.005 \\
\hline 188 & 0 & 0 & 0 & 0 & 0.013 & 0.005 \\
\hline 189 & 0.007 & 0 & 0.004 & 0 & 0 & 0 \\
\hline 190 & 0.007 & 0.013 & 0.009 & 0 & 0 & 0 \\
\hline 191 & 0.013 & 0 & 0.009 & 0 & 0 & 0 \\
\hline 193 & 0.007 & 0 & 0.004 & 0.008 & 0 & 0.005 \\
\hline 194 & 0 & 0 & 0 & 0.008 & 0 & 0.005 \\
\hline 195 & 0 & 0.013 & 0.004 & 0 & 0 & 0 \\
\hline 197 & 0 & 0 & 0 & 0.008 & 0 & 0.005 \\
\hline 200 & 0.007 & 0 & 0.004 & 0.008 & 0.013 & 0.010 \\
\hline 203 & 0.007 & 0 & 0.004 & 0 & 0 & 0 \\
\hline 204 & 0 & 0 & 0 & 0.008 & 0 & 0.005 \\
\hline 206 & 0 & 0 & 0 & 0 & 0.025 & 0.010 \\
\hline 207 & 0 & 0.013 & 0.004 & 0 & 0 & 0 \\
\hline 208 & 0 & 0 & 0 & 0.008 & 0 & 0.005 \\
\hline 209 & 0 & 0 & 0 & 0 & 0.013 & 0.005 \\
\hline 211 & 0.007 & 0 & 0.004 & 0 & 0 & 0 \\
\hline 215 & 0 & 0.013 & 0.004 & 0 & 0 & 0 \\
\hline 217 & 0 & 0 & 0 & 0.008 & 0 & 0.005 \\
\hline 229 & 0 & 0 & 0 & 0.008 & 0 & 0.005 \\
\hline 239 & 0 & 0 & 0 & 0.008 & 0 & 0.005 \\
\hline 252 & 0 & 0 & 0 & 0.008 & 0 & 0.005 \\
\hline
\end{tabular}


Table E.4. Observed allele frequencies for the Ots 103 microsatellite locus in Auke and Pillar Creek pink salmon used for breeding experiments in 1996 and 1997.

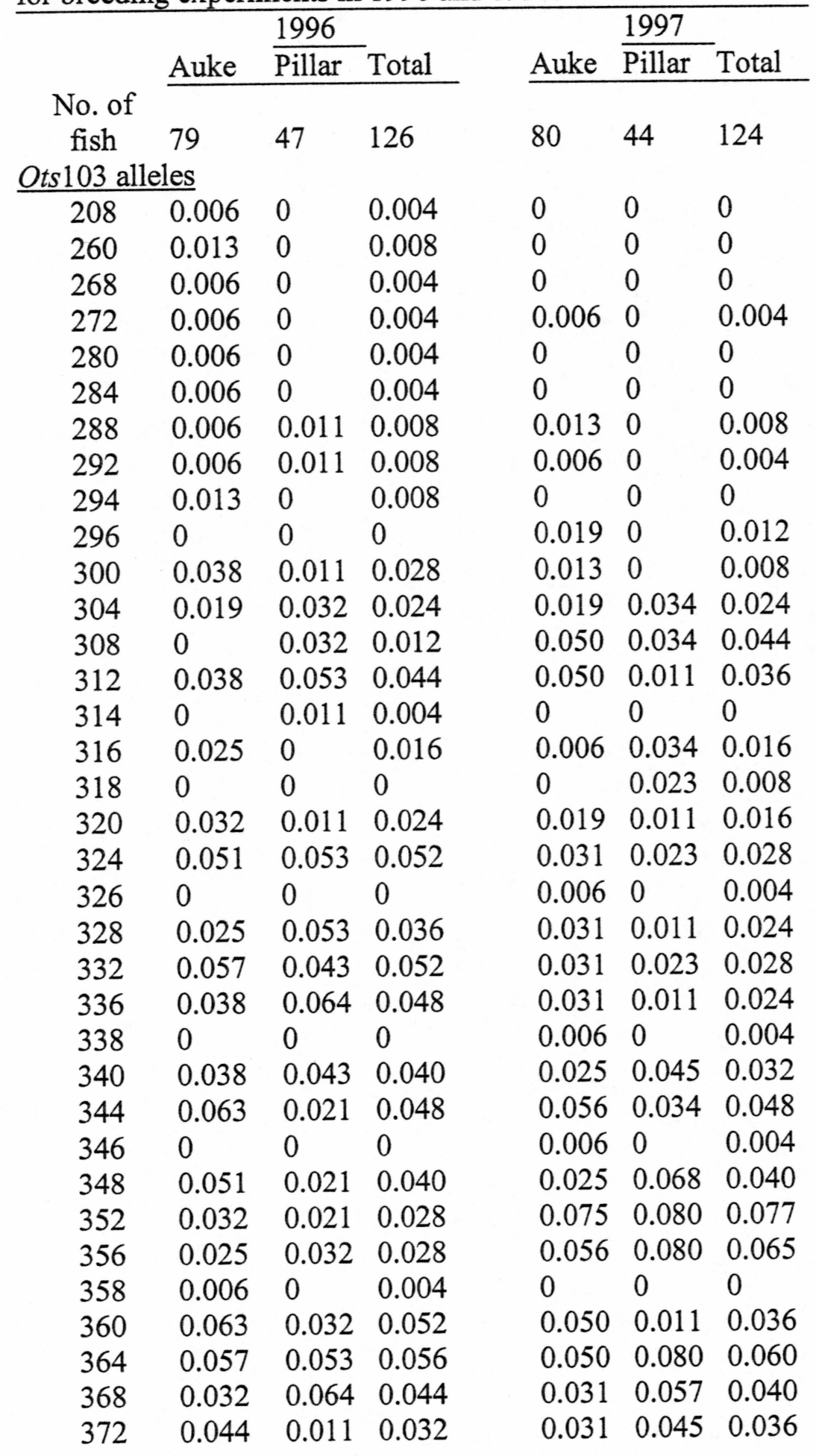


Table E.4. Continued.

\begin{tabular}{|c|c|c|c|c|c|c|}
\hline & & 1996 & & & 1997 & \\
\hline & Auke & Pillar & Total & Auke & Pillar & Total \\
\hline 376 & 0.025 & 0.053 & 0.036 & 0.013 & 0.011 & 0.012 \\
\hline 380 & 0.038 & 0.032 & 0.036 & 0.044 & 0.023 & 0.036 \\
\hline 384 & 0.013 & 0 & 0.008 & 0.050 & 0.057 & 0.052 \\
\hline 386 & 0 & 0 & 0 & 0 & 0.011 & 0.004 \\
\hline 388 & 0.025 & 0.032 & 0.028 & 0.038 & 0 & 0.024 \\
\hline 390 & 0 & 0.011 & 0.004 & 0 & 0 & 0 \\
\hline 392 & 0.013 & 0.032 & 0.020 & 0.025 & 0.045 & 0.032 \\
\hline 396 & 0.013 & 0.064 & 0.032 & 0.019 & 0 & 0.012 \\
\hline 398 & 0 & 0 & 0 & 0 & 0.011 & 0.004 \\
\hline 400 & 0 & 0.021 & 0.008 & 0.025 & 0.023 & 0.024 \\
\hline 404 & 0.013 & 0.011 & 0.012 & 0 & 0.045 & 0.016 \\
\hline 408 & 0.019 & 0.011 & 0.016 & 0.006 & 0 & 0.004 \\
\hline 412 & 0.006 & 0.011 & 0.008 & 0.006 & 0.011 & 0.008 \\
\hline 416 & 0 & 0 & 0 & 0.006 & 0 & 0.004 \\
\hline 420 & 0.006 & 0.011 & 0.008 & 0 & 0.011 & 0.004 \\
\hline 424 & 0.006 & 0.021 & 0.012 & 0 & 0 & 0 \\
\hline 428 & 0 & 0 & 0 & 0.013 & 0 & 0.008 \\
\hline 432 & 0 & 0 & 0 & 0 & 0.034 & 0.012 \\
\hline 436 & 0 & 0 & 0 & 0.006 & 0 & 0.004 \\
\hline 444 & 0.006 & 0 & 0.004 & 0 & 0 & 0 \\
\hline 448 & 0 & 0 & 0 & 0.006 & 0 & 0.004 \\
\hline 450 & 0.006 & 0 & 0.004 & 0 & 0 & 0 \\
\hline 452 & 0 & 0.011 & 0.004 & 0 & 0 & 0 \\
\hline 497 & 0.006 & 0 & 0.004 & 0 & 0 & 0 \\
\hline
\end{tabular}


Table E.5. Observed allele frequencies for the Ots 1

microsatellite locus in Auke and Pillar Creek pink salmon used for breeding experiments in 1996 and 1997.

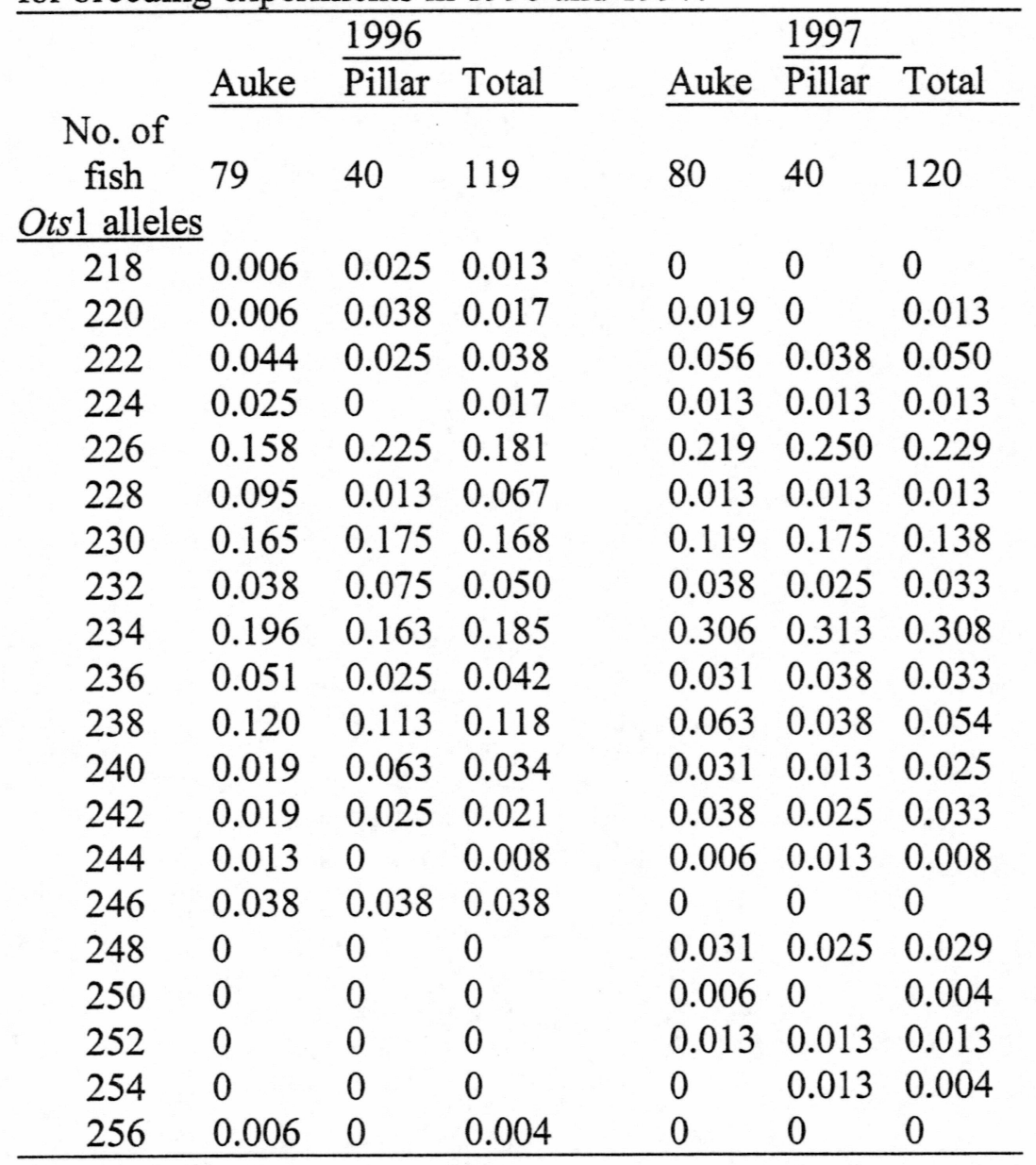


Table E.6. Observed allele frequencies for the Ssa 197

microsatellite locus in Auke and Pillar Creek pink salmon used for breeding experiments in 1996 and 1997.

\begin{tabular}{|c|c|c|c|c|c|c|}
\hline & Auke & $\frac{1996}{\text { Pillar }}$ & Total & Auke & $\frac{1997}{\text { Pillar }}$ & Total \\
\hline $\begin{array}{l}\text { No. of } \\
\text { fish }\end{array}$ & 80 & 40 & 120 & 74 & 42 & 116 \\
\hline \multicolumn{7}{|c|}{ Ssa197 alleles } \\
\hline 116 & 0 & 0.013 & 0.004 & 0.007 & 0 & 0.004 \\
\hline 122 & 0 & 0 & 0 & 0.007 & 0 & 0.004 \\
\hline 124 & 0.006 & 0.038 & 0.017 & 0.040 & 0.012 & 0.030 \\
\hline 128 & 0.038 & 0.013 & 0.029 & 0.020 & 0.071 & 0.039 \\
\hline 132 & 0.025 & 0.038 & 0.029 & 0.040 & 0.036 & 0.039 \\
\hline 136 & 0.044 & 0.100 & 0.063 & 0.060 & 0.036 & 0.052 \\
\hline 140 & 0.106 & 0.063 & 0.092 & 0.094 & 0.095 & 0.094 \\
\hline 144 & 0.144 & 0.163 & 0.150 & 0.101 & 0.095 & 0.099 \\
\hline 148 & 0.119 & 0.125 & 0.121 & 0.074 & 0.107 & 0.086 \\
\hline 150 & 0 & 0 & 0 & 0 & 0.024 & 0.009 \\
\hline 152 & 0.100 & 0.113 & 0.104 & 0.067 & 0.048 & 0.060 \\
\hline 156 & 0.088 & 0.088 & 0.088 & 0.074 & 0.131 & 0.094 \\
\hline 160 & 0.063 & 0.038 & 0.054 & 0.067 & 0.083 & 0.073 \\
\hline 162 & 0 & 0 & 0 & 0 & 0.012 & 0.004 \\
\hline 164 & 0.063 & 0.025 & 0.050 & 0.054 & 0.036 & 0.047 \\
\hline 168 & 0.044 & 0.038 & 0.042 & 0.040 & 0.024 & 0.034 \\
\hline 172 & 0.038 & 0.013 & 0.029 & 0 & 0 & 0 \\
\hline 176 & 0.025 & 0.038 & 0.029 & 0.047 & 0.048 & 0.047 \\
\hline 180 & 0.044 & 0 & 0.029 & 0.013 & 0.012 & 0.013 \\
\hline 184 & 0.006 & 0.013 & 0.008 & 0.040 & 0 & 0.026 \\
\hline 188 & 0 & 0.013 & 0.004 & 0.007 & 0.012 & 0.009 \\
\hline 192 & 0 & 0 & 0 & 0.007 & 0 & 0.004 \\
\hline 196 & 0 & 0 & 0 & 0.007 & 0 & 0.004 \\
\hline 204 & 0 & 0 & 0 & 0 & 0.012 & 0.004 \\
\hline 208 & 0 & 0 & 0 & 0 & 0.012 & 0.004 \\
\hline null & 0.050 & 0.075 & 0.058 & 0.134 & 0.095 & 0.120 \\
\hline
\end{tabular}


General Conclusion

Hybrids between two spatially separated Pacific salmon populations exhibited reduced survival due to outbreeding depression, and evidence of both epistatic and non-epistatic effects was observed. It does not appear that a decreased local homing ability, or increased variability in family size accounted for the decrease in hybrid survival. Whether due to non-epistatic or epistatic effects, the decrease in hybrid survival could jeopardize biodiversity of the wild stocks if repeated introductions are made. Small, onetime introductions may be of minor concern because natural selection might be expected to remove maladapted genotypes rapidly from a population; however, repeated introductions or development of non-local hatchery brood stocks have the potential to decrease productivity in local wild streams. The possibility of outbreeding depression suggests that broodstocks should be developed from locally adapted natural populations and that salmon managers should consider the potentially detrimental effects of transplanting stocks from one hatchery to another. 